\title{
Essential role of Salmonella Enteritidis DNA adenine methylase in modulating inflammasome activation
}

\author{
Yaxin Guo ${ }^{1,2,3,4 \dagger}$, Dan Gu1, 2,3,4†, Tingting Huang ${ }^{1,2,3,4}$, Liyan Cao 1,2,3,4 , Xinyu Zhu 1,2,3,4, Yi Zhou1,2,3,4, \\ Kangru Wang ${ }^{1,2,3,4}$, Xilong Kang ${ }^{1,2,3,4}$, Chuang Meng ${ }^{1,2,3,4}$, Xinan Jiao ${ }^{1,2,3,4^{*}}$ and Zhiming Pan ${ }^{1,2,3,4^{*}}$ (i)
}

\begin{abstract}
Background: Salmonella Enteritidis (SE) is one of the major foodborne zoonotic pathogens of worldwide importance which can induce activation of NLRC4 and NLRP3 inflammasomes during infection. Given that the inflammasomes play an essential role in resisting bacterial infection, Salmonella has evolved various strategies to regulate activation of the inflammasome, most of which largely remain unclear.
\end{abstract}

Results: A transposon mutant library in SE strain C50336 was screened for the identification of the potential factors that regulate inflammasome activation. We found that T3SS-associated genes invC, prgH, and spaN were required for inflammasome activation in vitro. Interestingly, C50336 strains with deletion or overexpression of Dam were both defective in activation of caspase-1, secretion of IL-1 $\beta$ and phosphorylation of c-Jun N-terminal kinase (Jnk). Transcriptome sequencing (RNA-seq) results showed that most of the differentially expressed genes and enriched KEGG pathways between the C50336-VS-C50336 $\Delta$ dam and C50336-VS-C50336::dam groups overlapped, which includes multiple signaling pathways related to the inflammasome. C50336 $\Delta$ dam and C50336::dam were both found to be defective in suppressing the expression of several anti-inflammasome factors. Moreover, overexpression of Dam in macrophages by lentiviral infection could specifically enhance the activation of NLRP3 inflammasome independently via promoting the Jnk pathway.

Conclusions: These data indicated that Dam was essential for modulating inflammasome activation during SE infection, there were complex and dynamic interplays between Dam and the inflammasome under different conditions. New insights were provided about the battle between SE and host innate immunological mechanisms.

Keywords: Salmonella Enteritidis, DNA adenine methylase, Inflammasome, Cytotoxicity, Caspase-1, Interleukin-1 $\beta$

\section{Background}

Salmonella enterica subsp. enterica is a Gram-negative facultative intracellular bacterial pathogen that causes over 1.3 billion illnesses and 200,000 deaths in humans annually worldwide [1]. Salmonellosis ranges from self-limiting gastroenteritis to lethal bacteremia in immunocompromised

\footnotetext{
*Correspondence: jiao@yzu.edu.cn; zmpan@yzu.edu.cn

${ }^{\dagger}$ Yaxin Guo and Dan Gu contributed equally to this work.

'Jiangsu Key Laboratory of Zoonosis, Yangzhou University, Yangzhou 225009, Jiangsu, China

Full list of author information is available at the end of the article
}

individuals [2]. Although more than 2500 different serotypes have been discovered, Salmonella enterica subsp. enterica serotype Enteritidis (SE) is one of the most important serovars transmitted from animals to humans and has replaced Salmonella enterica subsp. enterica serotype Typhimurium (ST) as the primary cause of salmonellosis globally since 1980 [3]. SE has been one of the major causes of outbreaks of food poisoning, poultry meat, eggs, and products are considered to be the major source of infection [4]. SE infection is a major public health problem, which could also cause

(c) The Author(s). 2020 Open Access This article is licensed under a Creative Commons Attribution 4.0 International License, which permits use, sharing, adaptation, distribution and reproduction in any medium or format, as long as you give appropriate credit to the original author(s) and the source, provide a link to the Creative Commons licence, and indicate if changes were made. The images or other third party material in this article are included in the article's Creative Commons licence, unless indicated otherwise in a credit line to the material. If material is not included in the article's Creative Commons licence and your intended use is not permitted by statutory regulation or exceeds the permitted use, you will need to obtain permission directly from the copyright holder. To view a copy of this licence, visit http://creativecommons.org/licenses/by/4.0/. The Creative Commons Public Domain Dedication waiver (http://creativecommons.org/publicdomain/zero/1.0/) applies to the data made available in this article, unless otherwise stated in a credit line to the data. 
severe economic losses in the poultry industry worldwide [5]. The elucidation of the host anti-infection immunity mechanism and development of new therapeutic strategies against SE infection would be of great importance.

After invading the host through the gastrointestinal tract, Salmonella traverses the epithelial barrier either through invasion of intestinal epithelial and microfold cells overlying Peyer's Patches or capture by $\mathrm{CD} 18^{+}$ immune cells directly from the intestinal lumen [6]. Salmonella cells that survive and replicate within macrophages are critical for the infection to extend beyond the intestinal mucosa [7]. The ability of Salmonella to invade host cells is dependent upon the Salmonella pathogenicity island-1 (SPI-1)-encoded type III secretion system (T3SS) which injects effector proteins into the host cell cytosol to modulate cellular responses, while the SPI-2 T3SS subsequently translocates virulence proteins to subvert the bactericidal properties of macrophages and create a specialized Salmonella-containing vacuole (SCV) for replication [8]. This special intracellular lifestyle exposes Salmonella to detection by inflammasomes, which have been identified as playing an essential role in the innate immune response against Salmonella infection [9].

Inflammasomes are cytoplasmic multi-protein sensors consisting of varying protein components, generally including pattern recognition receptors (PRRs, such as Nod-like receptors (NLRs) and melanoma 2 (AIM2)-like receptor), an adaptor protein ASC (apoptosis-associated speck-like proteins containing caspase recruitment domains), and an effector subunit caspase (primarily caspase-1) [10]. It is widely reported that NLRP3 and NLRC4 inflammasomes are activated during Salmonella infection [11]. After Salmonella invades host cells, the T3SS apparatus and pore-forming toxins are detected by NLRP3, while NLRC4 recognizes bacterial flagellin, T3SS needle, and basal rod proteins [12]. Inflammasome assembly is triggered to activate pro-caspase- 1 cleavage, leading to cleavage and secretion of caspase-1-dependent pro-inflammatory cytokines interleukin-1 $\beta$ (IL-1 $\beta$ ) and IL-18 and rapid lytic cell death known as pyroptosis [13]. Salmonella cells are subsequently released and exposed to neutrophil-mediated killing, which are recruited by IL-1 $\beta$ [14].

A previous study demonstrated that mice deficient in caspase-1, IL-1 $\beta$, or IL-18 succumbed to infection earlier than wild type (WT) mice and had significantly higher Salmonella burdens in the Peyer's patches, mesenteric lymph nodes, and spleens [15]. In addition, genetic ablation of both NLRC4 and NLRP3 in mice leads to increased susceptibility to Salmonella infection [16]. Given the emphasis on inflammasomes in resisting bacterial infection, Salmonella has evolved multiple mechanisms to avoid or delay inflammasome activation [17]. To evade NLRC4 detection, flagellin and SPI-1 are strongly repressed in the intracellular environment through the PhoP-PhoQ regulatory system of Salmonella [18]. A recent study reported that Salmonella uses the SPI-1 T3SS effector SopB to suppress NLRC4 inflammasome activation by preventing ASC oligomerization [19]. Salmonella can also down-regulate NLRC4 and interfere with other host pathways to regulate inflammasome activation, such as autophagy [20]. In addition, Salmonella tricarboxylic acid cycle enzymes have been reported to limit NLRP3 inflammasome-dependent antibacterial immune responses through mitochondrial reactive oxygen species [21]. However, the many strategies of Salmonella regulation of the activation of the inflammasome remain largely unknown.

Until now, research on the interplay between Salmonella and inflammasomes has focused on ST, with SE inflammasomes still poorly understood. To identify potential factors involved in regulating the activation of the inflammasome, we constructed a transposon mutant library in SE strain C50336 and screened for increased or decreased inflammasome activation in the mouse macrophage cell line J774A.1. Sequencing of candidate mutants identified dam, the gene encoding DNA adenine methylase, which is an essential factor for Salmonella virulence [22]. Intriguingly, both deletion and overexpression of Dam failed to induce inflammasome activation, and RNA-seq assays suggested that the absence and overexpression of Dam had similar effects on infected macrophages. Notably, overexpression of Dam in J774A.1 cells by lentiviral infection promoted activation of the NLRP3 inflammasome. Collectively, these results indicated that SE Dam plays a critical role in inflammasome activation during infection.

\section{Results}

\section{Screening candidate mutants for alterations in} inflammasome activation

To screen potential genes involved in modulating the activation of the inflammasome, a mariner-based transposon (TnpSC189) mutant library in SE strain C50336 was generated. Thus far, 2062 transposon mutants have been tested individually, and candidate mutants were selected by increased or decreased Lactate dehydrogenase (LDH) release relative to the C50336 parental strain $4 \mathrm{~h}$ after infection of the mouse macrophage cell line J774A.1. Following the first round of screening, $106 \mathrm{mu}-$ tants were considered candidates for the second round of validation (Fig. 1a). The cytotoxicity induced by 29 mutants ( $Z$ score $\geq 2)$ was significantly higher than that induced by $C 50336$, while 77 mutants $(Z$ score $\leq-2)$ induced significant lower cytotoxicity. To verify the selected candidates, each was tested individually in another screening round. The candidate mutants were rescreened in J774A.1 cells, LDH release was quantified, 


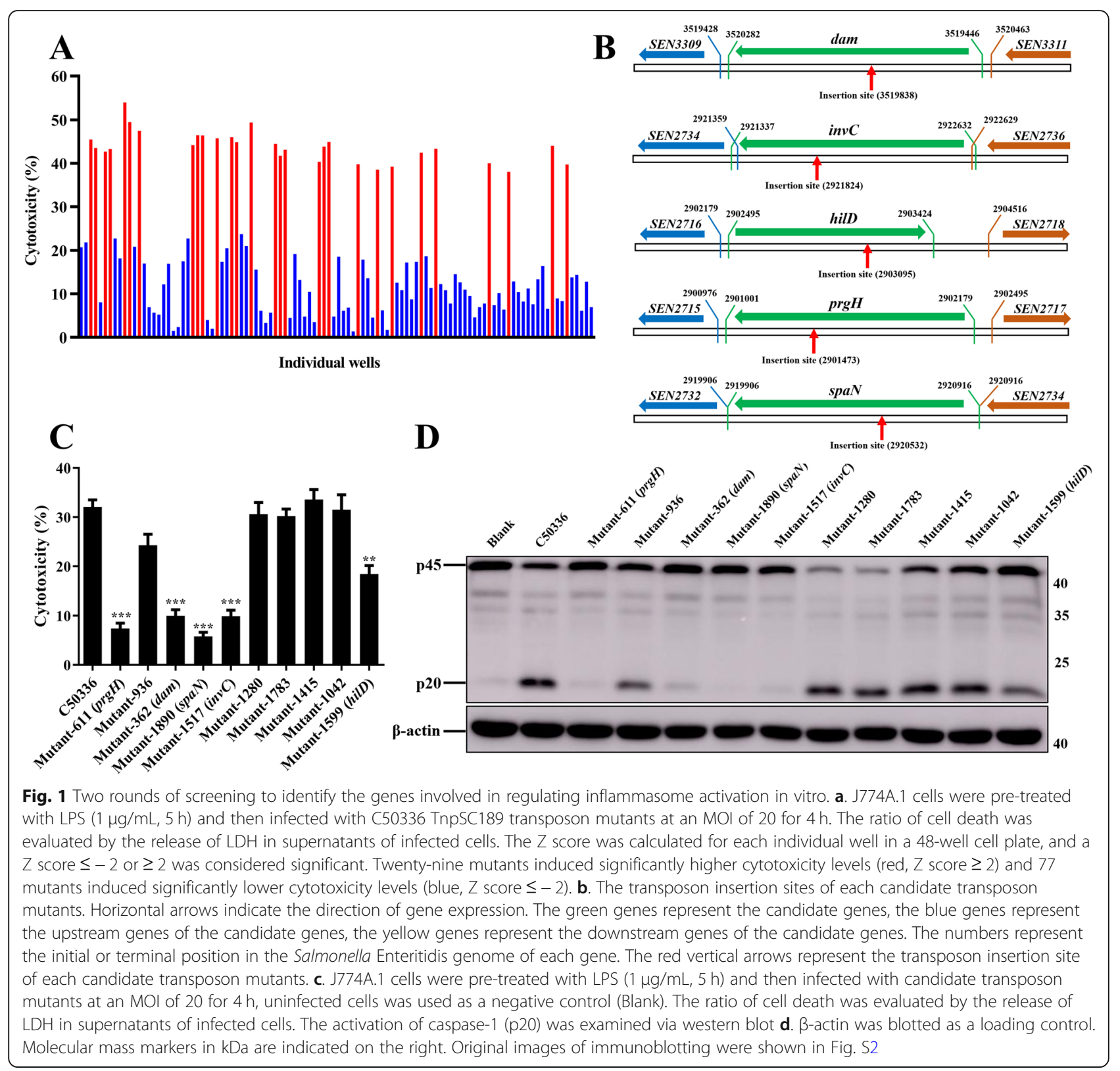

and caspase- 1 activation was determined by western blot. The candidate transposon mutants $611,362,1890$, 1517, and 1599 induced significant lower levels of cytotoxicity and activation of caspase- 1 compared to WT (Fig. 1c and d). The transposon insertion sequencing of the candidate mutants identified these five genes were dam, invC, hilD, prgH and spaN, the transposon insertion sites were shown in Fig. 1b. The dam gene encodes a DNA adenine methylase, invC encodes a FliI/YscN family ATPase, hilD encodes a transcriptional regulator, prgH encodes a T3SS inner membrane ring protein, and spaN encodes an SPI-1 T3SS protein.

\section{Identification of candidate genes regulate the} inflammasome activation

To further investigate the function of these five genes in regulating inflammasome activation, the in-frame deletion mutants of $d a m$, invC, hilD, prgH, and spaN genes were constructed. There was no significant difference in growth characteristics among WT strain, each mutant, complementation, and overexpression strains (Fig. S1). As shown in Fig. 2a, infection with dam, invC, prgH, and spaN mutant strains resulted in greatly decreased LDH release in comparison with J774A.1 cells infected by WT. We subsequently examined whether reduced cell 


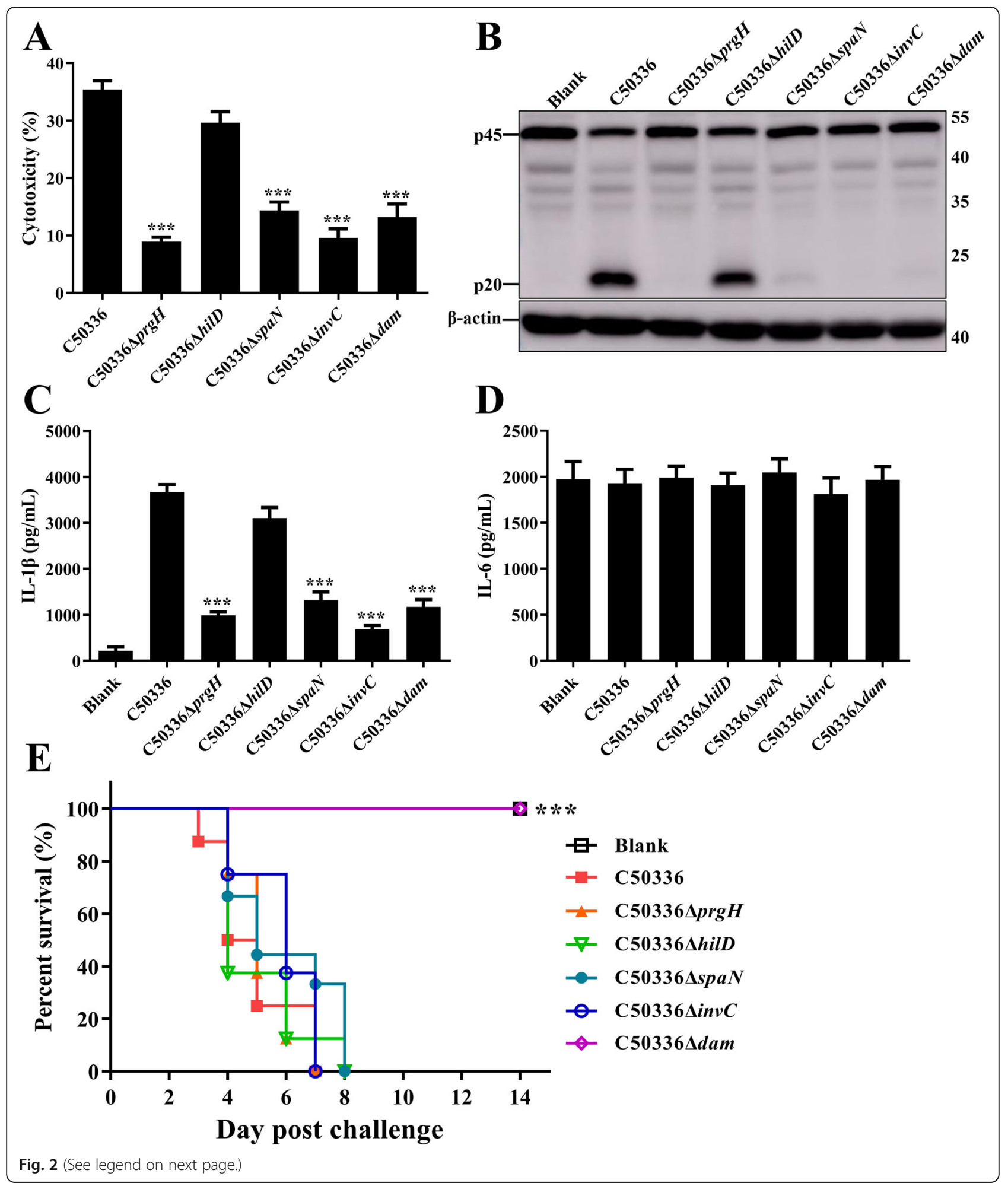


(See figure on previous page.)

Fig. 2 Deletion mutants of dam, invC, prgH, and spaN failed to induce inflammasome activation. J774A.1 cells were pre-treated with LPS (1 $\mu \mathrm{g} /$ $\mathrm{mL}, 5 \mathrm{~h}$ ) and then infected with WT strain C50336 and dam, invC, hilD, prgH, and spaN gene deletion mutants at an MOI of 20 for $4 \mathrm{~h}$, uninfected cells was used as a negative control (Blank). $\mathbf{a}$. The ratio of cell death was evaluated by the release of LDH in supernatants of infected cells. $\mathbf{b}$. The activation of caspase-1 (p20) was examined via western blot. $\beta$-actin was blotted as a loading control. Molecular mass markers in kDa are indicated on the right. Original images of immunoblotting were shown in Fig. S3. The production of IL-1 $\beta \mathbf{c}$ and IL-6 $\mathbf{d}$ in supernatants were examined via ELISA. *** $p<0.001$ for one-way ANOVA followed by Bonferroni's multiple comparison test indicate significant findings in comparison with cells infected with WT strain C50336. Data are presented as mean \pm SEM of triplicate samples per experimental condition from three independent experiments. e. C57BL/6 mice were intraperitoneally injected with PBS (negative control, Blank), C50336, and gene deletion mutants at a dose of $1 \times 10^{5} \mathrm{CFU}$ per mouse. The mortality was recorded over $14 \mathrm{dpc}$. ***, $p<0.001$ compared with the C50336-infected group by log-rank (Mantel-Cox) test for the survival curve

death was caused by decreased inflammasome activation. As expected, the WT triggered strong caspase-1 activation and IL-1 $\beta$ expression in infected J774A.1 cells, while the production of cleaved caspase-1 p20 subunits and caspase-1-dependent cytokine IL-1 $\beta$ was significantly suppressed in cells infected with dam, invC, prgH, or spaN deletion mutant strains (Fig. 2b and c). Simultaneously, to further verify whether these genes can specifically influence the inflammasome pathway, we also measured the levels of non-inflammasome inflammatory cytokine IL-6 in supernatants. There was no significant difference in IL-6 secretion between WT- and deletion mutant strains-infected cells (Fig. 2d). These results suggested that dam, invC, $\mathrm{prgH}$, and spaN specifically influenced inflammasome activation during SE infection in J774A.1 cells. In addition, the mouse was used as the animal model to determine the virulence of gene-deficient strains. None of the mice died in the C50336 dam-infected group, whereas all mice infected with other gene deletion mutants or WT C50336 (50) died within 8 days post-challenge (dpc) (Fig. 2e). No clinical symptoms were detected in the mice infected with C50336 $\triangle$ dam, suggesting that Dam played an important role in the virulence of SE.

\section{Identification of proteins transferred into host cells}

Salmonella injects various effector proteins into host cell cytosol to stimulate or interfere with cellular processes. To identify whether Dam, InvC, $\mathrm{PrgH}$, and SpaN can be translocated into the cytosol of infected cells, $\beta$-lactamase TEM-1 was fused with each of these four proteins. The intracellular translocation was assayed via fluorescence resonance energy transfer (FRET) in infected HeLa cells (Fig. 3a). Uninfected HeLa cells and cells infected with C50336 contain an empty plasmid pCX340 appeared green, indicating the absence of TEM-1 activity in these cells. While, no blue fluorescence was detected in cells infected with C50336-pCX340-invC and C50336-pCX340spaN, suggesting that the fusion proteins InvC-TEM and SpaN-TEM encoded by C50336 were not secreted and/or able to cleave the $\beta$-lactam ring of CCF2-AM. In contrast, infection with C50336 expressing Dam-TEM and PrgHTEM resulted in a significant population of blue fluorescent cells. The transfer efficiency of PrgH-TEM was about
$10.3 \%$ (Fig. 3b), while the expressed Dam-TEM was translocated at a higher efficiency ( 21.1\%). These data indicate that Dam and PrgH could be secreted and then translocated into the host cells during SE infection.

\section{Deletion of dam or prgH does not affect synthesis of inflammasome components}

Previous studies have shown that the expression of $\mathrm{PrgH}$ is regulated by Dam [23]. To further confirm the role of dam and $\mathrm{prgH}$ in regulating inflammasome activation, complementation strains and overexpression strains were constructed by employing the plasmid pMMB207. Primary bone marrow-derived macrophages (BMDMs) obtained from WT C57BL/6 mice were infected with indicated SE strains. The expression of NLRP3, NLRC4, ASC, and pro-IL-1 $\beta$ were analyzed by immunoblotting (Figs. 4 and 5). The results demonstrated that neither dam or $\mathrm{prgH}$ gene deletion nor overexpression could significantly suppress the expression of inflammasome components, indicating that the effect of Dam and PrgH on inflammasome activation was not achieved by influencing the synthesis of inflammasome components.

Similarly, LDH release was significantly decreased in BMDMs infected with C50336 $\Delta$ prgH or C50336 $\Delta$ dam as compared to WT strains, as was caspase- 1 activation and IL-1 $\beta$ secretion (Figs. 4 and 5 ). The decreased cytotoxicity and expression of caspase- 1 and IL- $1 \beta$ induced by $C 50336 \Delta \mathrm{prgH}$ was recovered to a normal level when infected with C50336 $\operatorname{prgH}:: \mathrm{prgH}$, whereas overexpression of $\mathrm{prgH}$ could not induce stronger inflammasome activation. However, the most interesting observation was that caspase- 1 activation, IL- $1 \beta$ secretion, and LDH release were all obviously suppressed in BMDMs infected with complementation strain C50336 ddam::dam and overexpression strain C50336::dam (Fig. 5), suggesting Dam may play a variety of roles in modulating inflammasome activation during SE infection. The addition of IPTG during the culture of bacteria containing plasmid pMMB207 had a great effect on promoting the expression of target proteins [24]. Moreover, we found that SE bearing plasmid pMMB207-dam failed to activate the inflammasome, and seemed reasonable because the expressions of Dam in both the complementation strain and overexpression strain were 


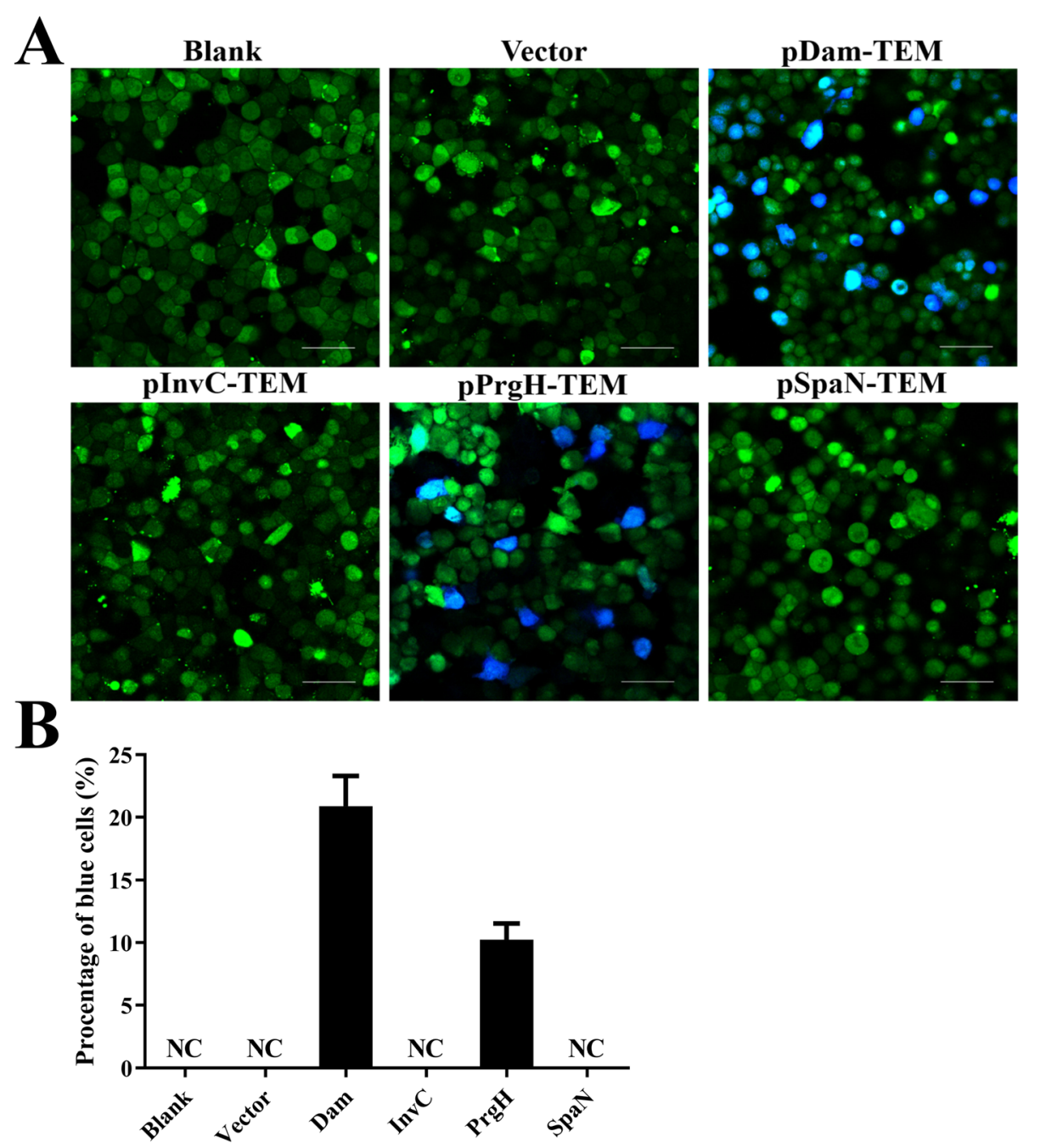

Fig. 3 Target proteins Dam and PrgH were able to be translocated into the infected cells. HeLa cells were infected with WT C50336 bearing empty plasmid pCX340 or expressing different TEM-1 fusion proteins at an MOI of 100, uninfected HeLa cells was used as a negative control (Blank). Cells were washed and loaded with CCF2-AM after infection. a. Translocation of TEM-1 fusion proteins into the cell cytosol results in cleavage of CCF2-AM, emission of blue fluorescence revealed the activity of TEM $\beta$-lactamase, whereas uncleaved CCF2-AM emitted green fluorescence. Scale bar, $50 \mu \mathrm{m}$. b. The percentages of cells emitting blue fluorescence. For a particular cell well, six pictures were taken and approximately 1200-2000 cells were counted. Each picture was considered an independent observation and used to calculate the percentage of blue fluorescent cells. Data are presented as mean \pm SEM of triplicate samples per experimental condition from three independent experiments

maintained at a high level in the presence of IPTG. The expression level of Dam may be a key factor in regulating inflammasome activation.

To verify this hypothesis, the complementation strains and overexpression strains cultured without IPTG were used to infect WT BMDMs. The results showed that the complementation strain induced a significant enhancement of cytotoxicity, bioactive IL- $1 \beta$ and caspase- 1 secretion compared to C50336 $\triangle$ dam (Fig. 6), although the ability of C50336 ddam::dam to activate the inflammasome did not return to a normal level like C50336 $\mathrm{prgH}$ :: prgH induction. Furthermore, the C50336::dam cultured without IPTG still induced relatively lower levels of cytotoxicity, IL-1 $\beta$ and caspase-1 compared with C50336-
pMMB207. However, inflammasome activation induced by C50336::dam was significantly stronger than that induced by C50336 $\Delta$ dam. Taken together, our results demonstrate that different expression levels of Dam could lead to different degrees of inflammasome activation during SE infection in vivo, suggesting that there may be a complex interaction between Dam and the inflammasome.

Global transcriptome of J774A.1 cells infected with SE Since the expression level of Dam was found to be important in regulating inflammasome activation, transcriptome analysis of J774A.1 cells infected with C50336, C50336 dam, or C50336::dam (cultured with IPTG) strains were carried out. The criteria for the selection of 
A

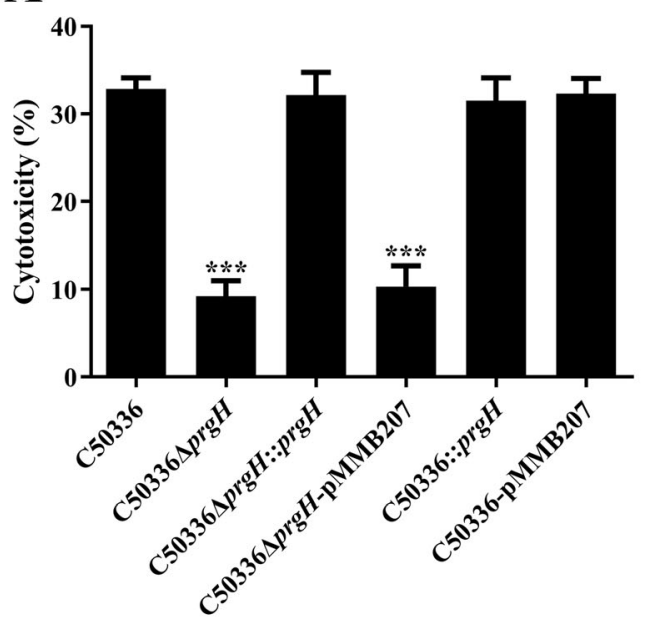

C

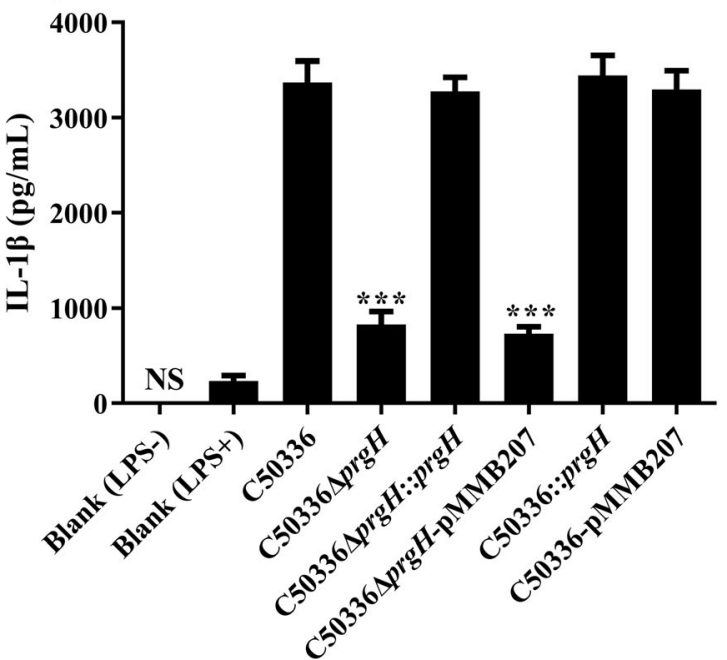

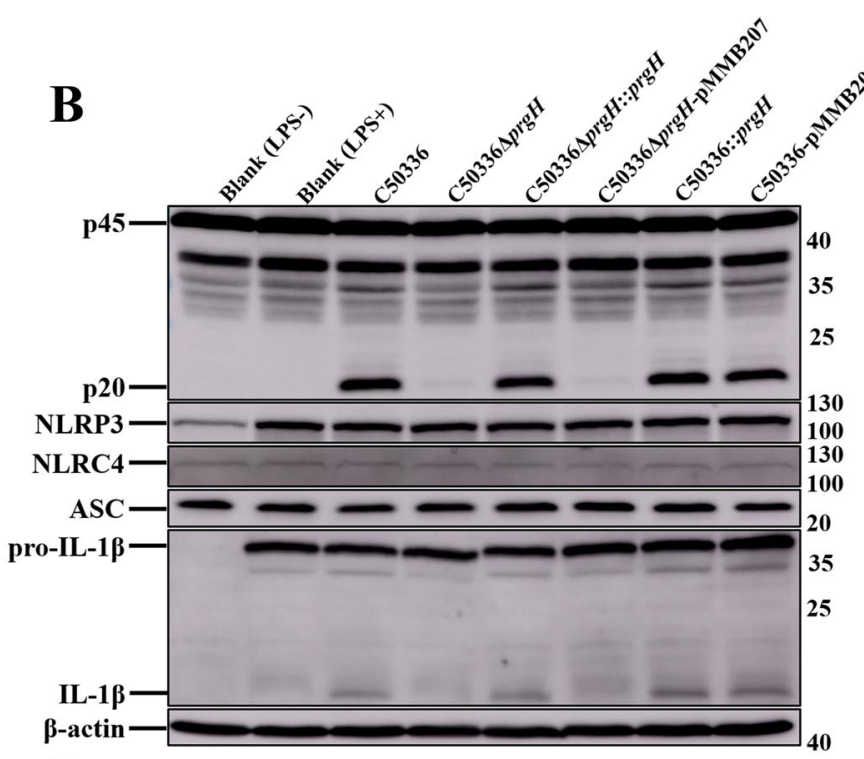

D

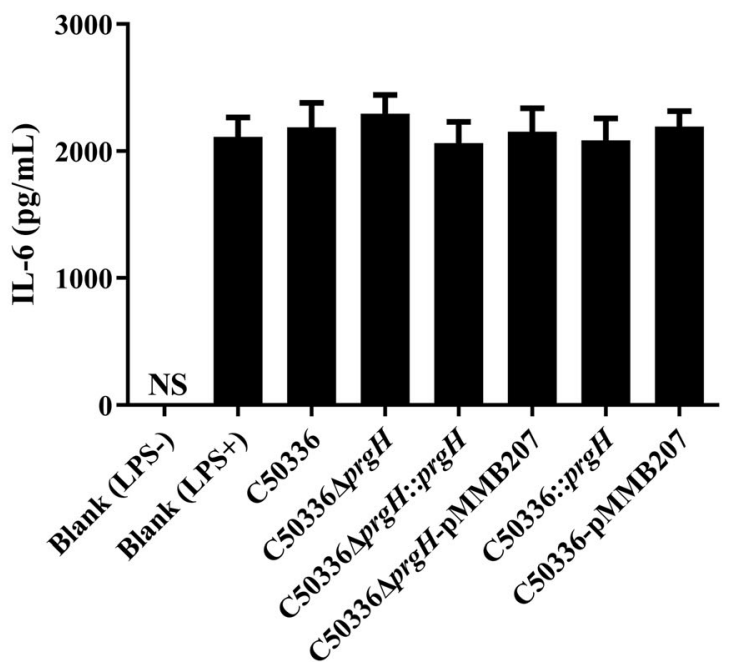

Fig. 4 Deletion of $\mathrm{prgH}$ did not influence the synthesis of inflammasome components. C57BL/6 BMDMs were pre-treated with LPS (1 $\mu \mathrm{g} / \mathrm{mL})$ for $5 \mathrm{~h}$ (untreated and uninfected BMDMs was used as a negative control, Blank LPS-), and then infected with C50336, C50336 $\Delta$ prgH,

C50336 AprgH::prgH, C50336 D prgH-pMMB207, C50336::prgH, or C50336-pMMB207 at an MOl of 20 for $4 \mathrm{~h}$, uninfected BMDMs was used as another negative control (Blank LPS+). Bacteria bearing pMMB207 plasmids were cultured with IPTG $(0.5 \mathrm{mM})$. $\mathbf{a}$. The ratio of cell death was evaluated by the release of LDH in the supernatants. $\mathbf{b}$. The expression of caspase-1, NLRP3, NLRC4, ASC, and pro-IL-1 $\beta$ were analyzed by immunoblotting. $\beta$ actin was blotted as a loading control. Molecular mass markers in $\mathrm{kDa}$ are indicated on the right. Original images of immunoblotting were shown in Fig. S4. The production of $\mathrm{IL}-1 \beta \mathbf{c}$ and IL-6 d in the supernatants were examined via ELISA. ${ }^{* *} p<0.001$ for one-way ANOVA followed by Bonferroni's multiple comparison test indicate significant findings in comparison with cells infected with WT strain C50336. Data are presented as mean \pm SEM of triplicate samples per experimental condition from three independent experiments

differentially expressed genes (DEGs) were false discovery rate $(p$-adjust $)<0.05$ and a fold change value $\mid \log _{2-}$ Ratio $\mid \geq 1$. In total, 2237 DEGs were identified between the C50336-infected and C50336 $\Delta$ dam-infected groups, including 2039 up-regulated genes and 198 downregulated genes (Fig. 7a). Similarly, 2526 DEGs were found in the C50336-infected group compared with the C50336:: dam-infected group, with 2151 genes up-regulated and
375 genes downregulated (Fig. 7b). Only 56 DEGs were screened between the C50336 $\Delta$ dam-infected and the C50336::dam-infected groups (Fig. 7c), indicating that the gene expression pattern was similar between these two groups, which was further confirmed by Venn diagram analysis. As shown in Fig. 7d, 1738 overlapping genes were identified between the C50336-VSC50336 ddam and C50336-VS-C50336::dam groups, 


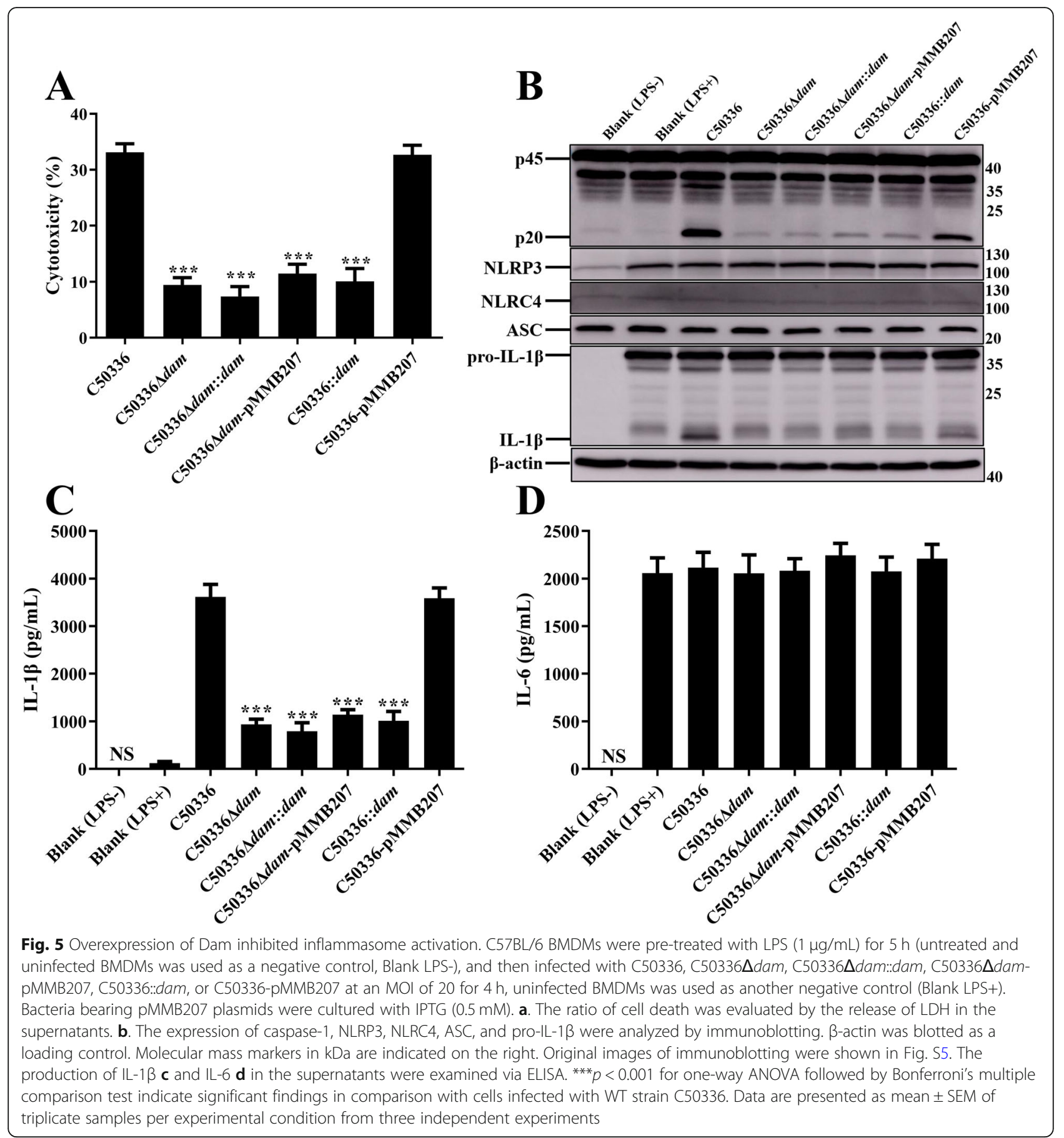

suggesting that the deletion and overexpression of Dam may had a similar effect in modulating cell responses during SE infection.

Kyoto Encyclopedia of Genes and Genomes (KEGG) pathway enrichment analysis was performed with the DEGs between these three groups to identify the potential pathways and genes affected by Dam. The 30 pathways that were most significantly enriched were shown in Fig. 8. The most significantly enriched pathways were related to cancer, mitogen-activated protein kinase (MAPK) signaling, and human papillomavirus infection between the C50336-infected group and the C50336 $\Delta$ dam-infected group (Fig. 8a). The significantly enriched pathways were mainly involved in viral carcinogenesis, MAPK signaling, and tumor necrosis factor (TNF) signaling between the C50336-infected group and the C50336::dam-infected group (Fig. 8b). As expected, 18 overlapping pathways were found in the top 30 significantly enriched pathways between 


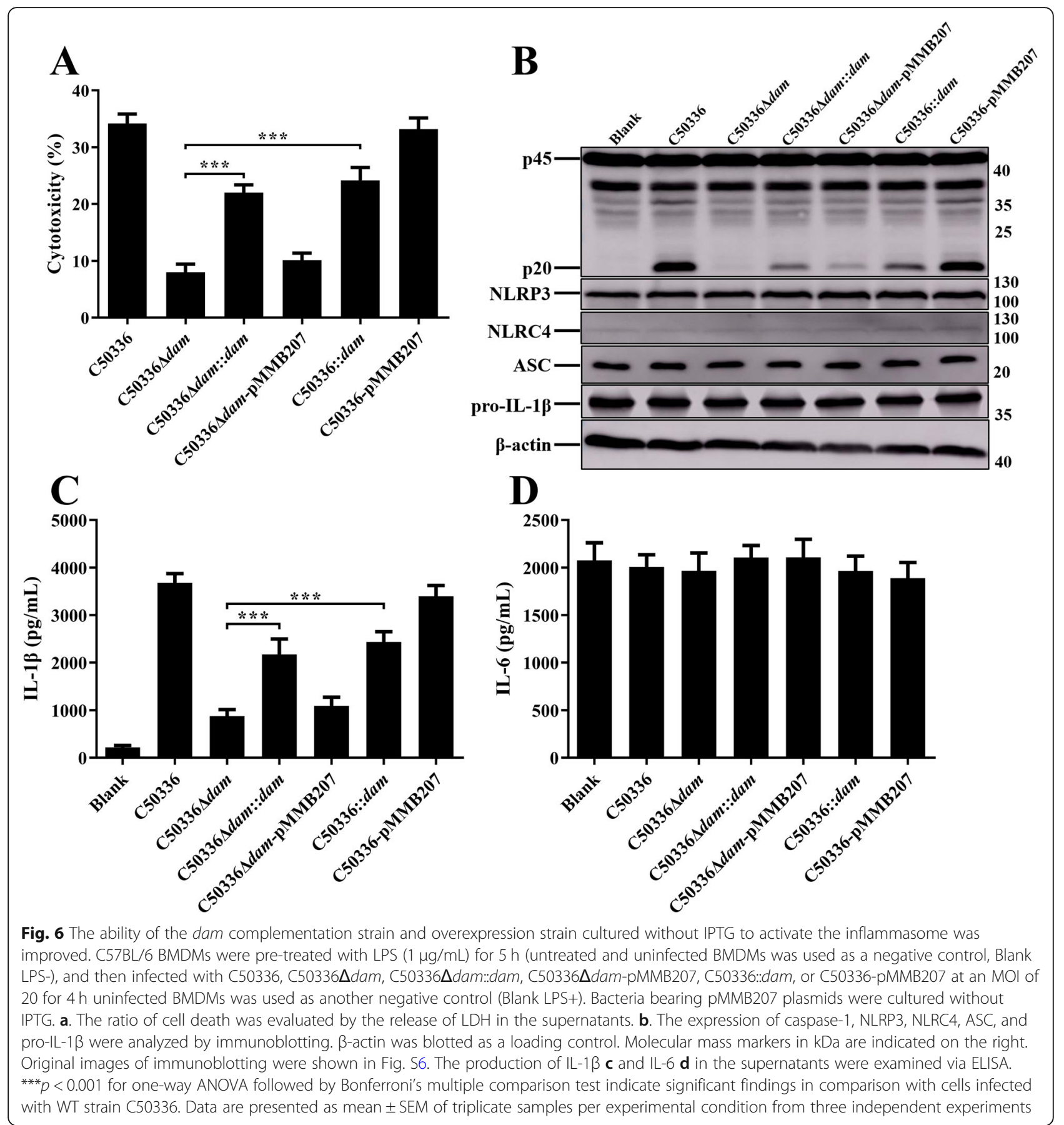

the C50336-VS-C50336 $\Delta$ dam group and the C50336VS-C50336::dam group, which further suggested that the deletion and overexpression of Dam may play a similar role in regulating cellular processes during SE infection. In contrast, the most significantly enriched pathways within a maximum of 10 DEGs were cytokine-cytokine receptor interaction, TNF signaling, IL-17 signaling, and AGE-RAGE signaling in diabetic complications between the C50336 $\Delta$ dam-infected group and C50336::dam-infected group (Fig. 8c).
Identification of the expression patterns of DEGs based on quantitative real-time $P C R$

We verifed RNA-seq results by selecting the differentially expressed genes in infected J774A.1 cells including 7 overlapping DEGs from MAPK signaling pathway, 7 overlapping DEGs from transforming growth factor- $\beta$ (TGF- $\beta$ ) signaling pathway, 8 overlapping DEGs from TNF signaling pathway, and 8 overlapping DEGs from forkhead box, sub-group $\mathrm{O}$ (FoxO) signaling pathway between the C50336-VS-C50336 ddam and C50336-VS- 


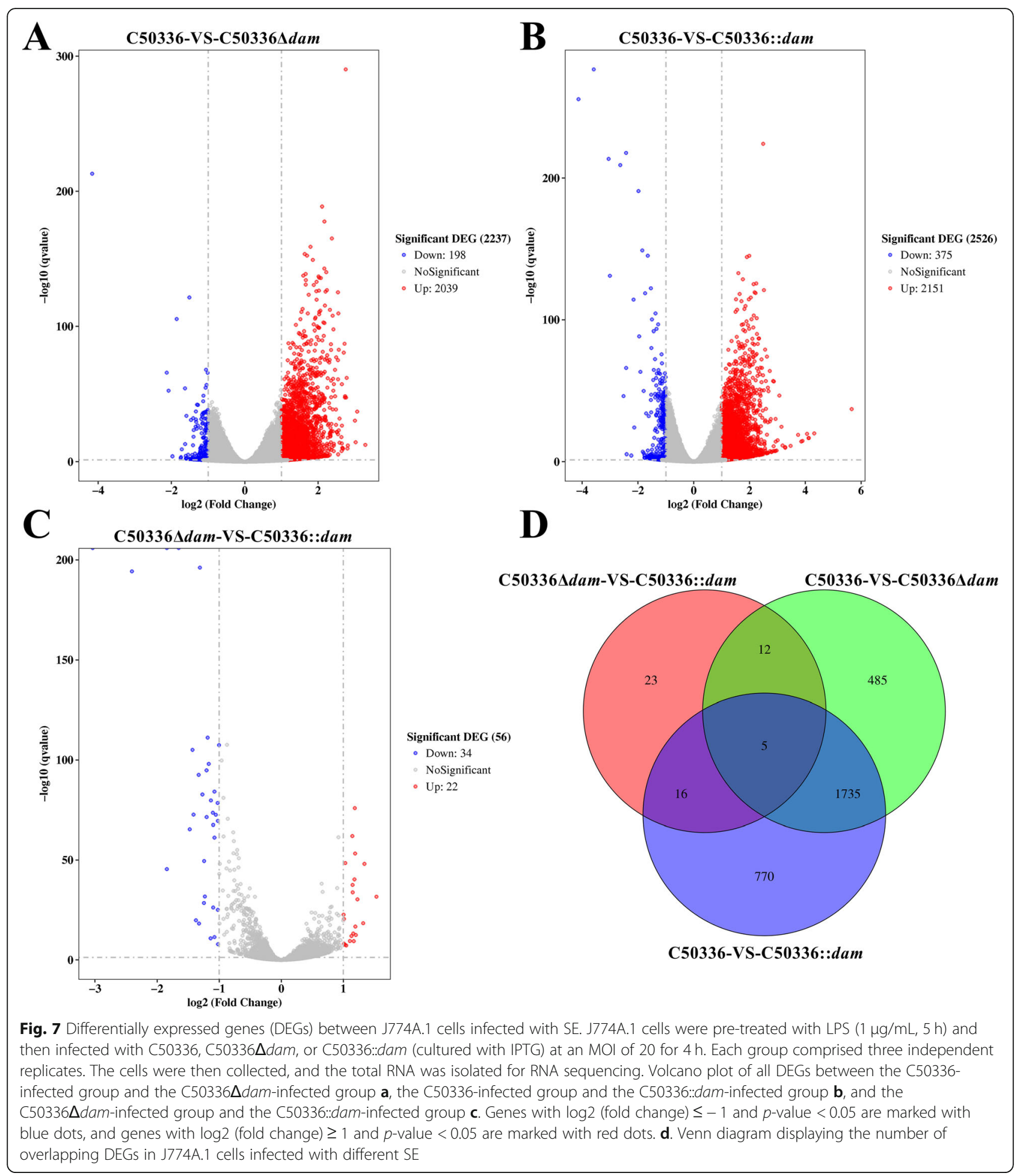

C50336::dam groups. Mouse glyceraldehyde-3-phosphate dehydrogenase (GAPDH) was used to normalize the gene expression. The expression of the selected overlapping DEGs was consistent with the results of RNA-seq in both C50336-VS-C50336_dam (Fig. 9) and C50336-VS-C50336:: dam groups (Fig. 10). In addition, the fold changes of overlapping DEGs were similar between the C50336-VSC50336 $\Delta$ dam and C50336-VS-C50336::dam groups indicating that both deletion and overexpression of Dam played a similar role of regulating cellular processes during $\mathrm{SE}$ 


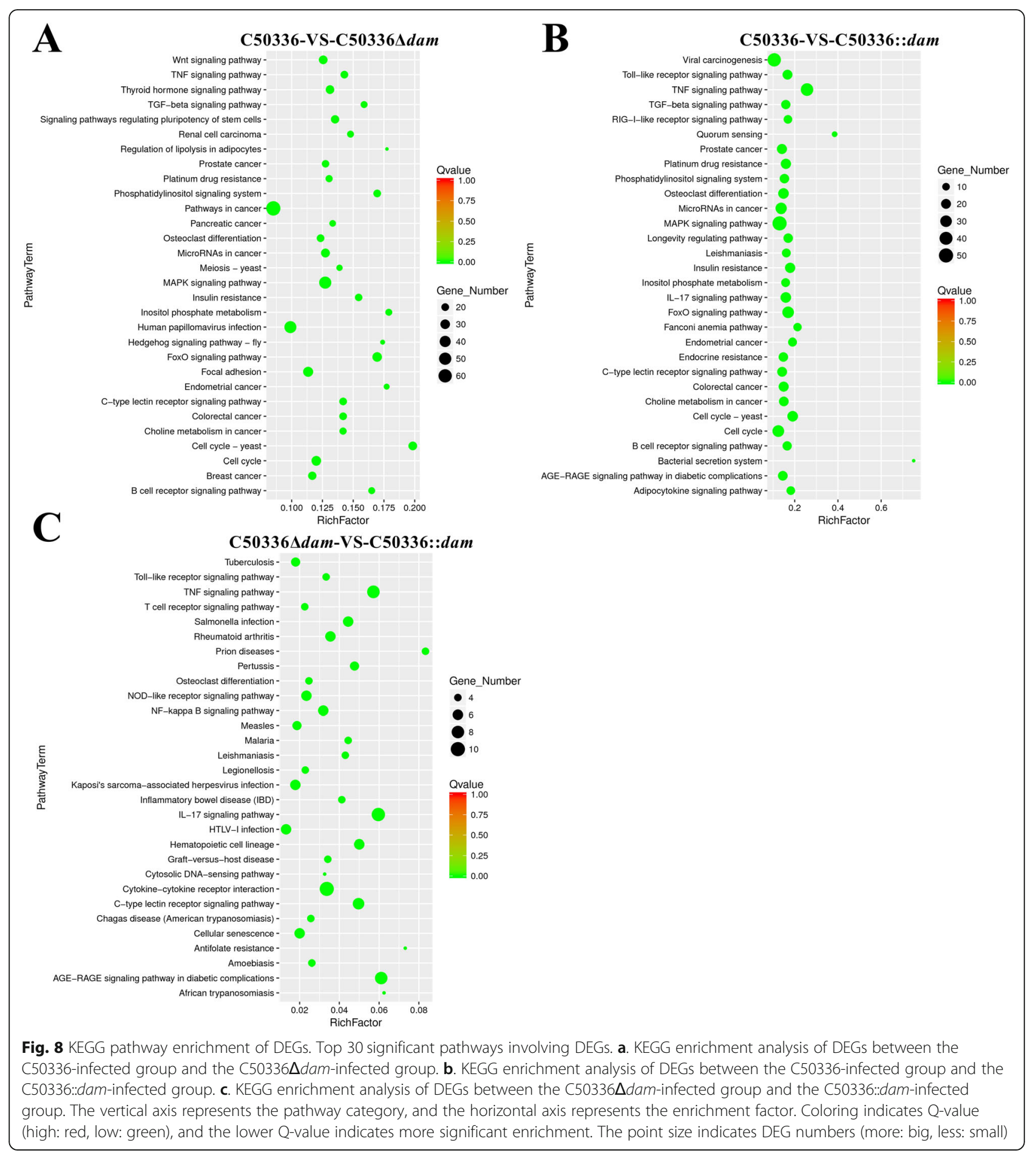

infection. These results demonstrated that the expression levels of Dam was essential for the regulation of these signaling pathways.

\section{Dam was required for Jnk pathway activation in vitro}

To further explore the mechanism of Dam regulates the activation of inflammasome, western blot was used to determined the activation of MAPK pathway based on the data of RNA-seq. The phosphorylation level of c-Jun $\mathrm{N}$-terminal kinase (Jnk) induced by dam mutant strain was significantly lower than that induced by C50336 in J774A.1 cells, which was accompanied with the decreased activation of caspase-1 (Fig. 11). The Jnk phosphorylation was more significantly induced by dam 


\section{C50336-VS-C50336 $\Delta$ dam}
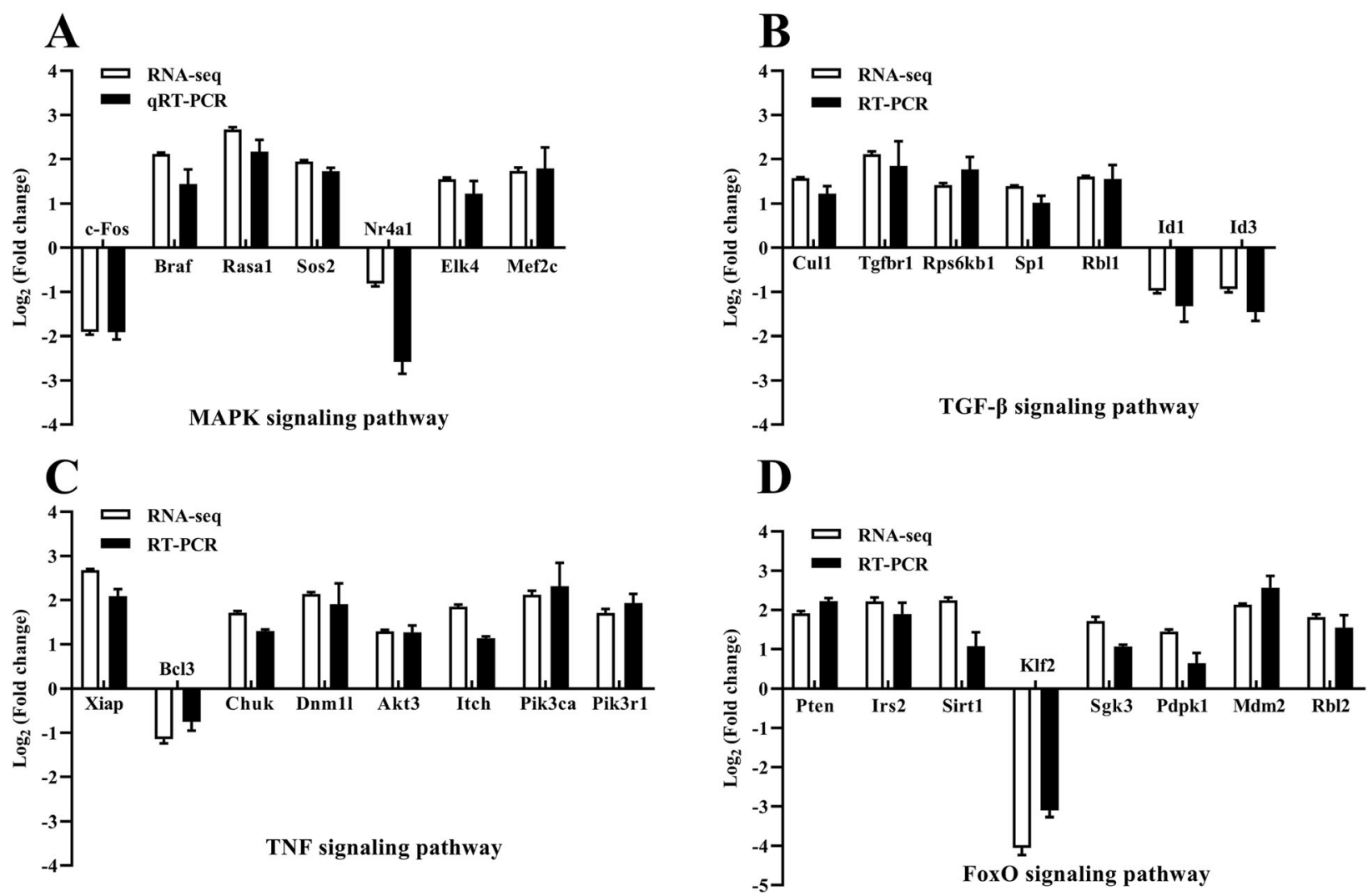

Fig. 9 qRT-PCR validation of expression levels of the overlapping DEGs from MAPK signaling pathway $\mathbf{a}$, TGF- $\beta$ signaling pathway $\mathbf{b}$, TNF signaling pathway $\mathbf{c}$, and FoxO signaling pathway $\mathbf{d}$ in the C50336-VS-C50336 $\Delta$ dam group. J774A.1 cells were pre-treated with LPS ( $1 \mu \mathrm{gg} / \mathrm{mL}, 5 \mathrm{~h})$ and then infected with C50336 or C50336 $\Delta$ dam at an MOI of 20 for $4 \mathrm{~h}$. Each group comprised three independent replicates. The cells were then collected, and the total RNA was isolated for qRT-PCR. The mRNA expression level was normalized against the mouse GAPDH transcript. Data are presented as mean \pm SEM of $\log _{2}$ (fold change) of triplicate samples

complementation strain than by C50336 $\Delta$ dam. In addition, the overexpression of Dam also induced a lower phosphorylation level of Jnk compared to WT. Furthermore, the phosphorylation level of p38 and extracellular regulated protein kinases $1 / 2$ (ERK1/2) induced by $C 50336 \triangle$ dam was slightly lower than that induced by C50336, which was not significant. These results suggested that deletion of dam blocked the Jnk pathway in infected macrophages, which led to the inhibition of inflammasome activation.

\section{Dam promoted NLRP3 inflammasome activation} independently via Jnk pathway in lentiviral infection assays

To further explore the effect of Dam on inflammasome activation, lentiviral vectors pGLV5-dam (EF1aF/GFP\&Puro) were constructed, and the lentivirus LV5-Dam particles were packaged and transfected into J774A.1 cells. To test the efficacy of lentivirus delivery into the macrophages, green fluorescent protein (GFP) expression was examined. The cells with LV5-Dam or LV5-negative lentivirus treatment exhibited robust GFP expression, indicating the effective infection of lentivirus in mice macrophages. After LPS priming, J774A.1 cells were stimulated with a classical NLRP3 inflammasome activator adenosine triphosphate (ATP, $1.25 \mathrm{mM}$ ). Significantly up-regulated inflammasome signals were detected in Dam-expressing J774A.1 cells, compared with those in negative lentivirus transduced cells and control cells (Fig. 12a and c). Furthermore, the expression of IL- 6 and the synthesis of NLRP3 inflammasome components, including NLRP3, ASC, and pro-IL-1 $\beta$ were not affected by lentiviral infection (Fig. 12b and c). In addition, the deletion of dam failed to induce Jnk phosphorylation in infected J774A.1 cells, the phosphorylation of Jnk was also determined by immunoblotting with the infection of lentivirus LV5-Dam. As expected, there was a significant 


\section{C50336-VS-C50336::dam}
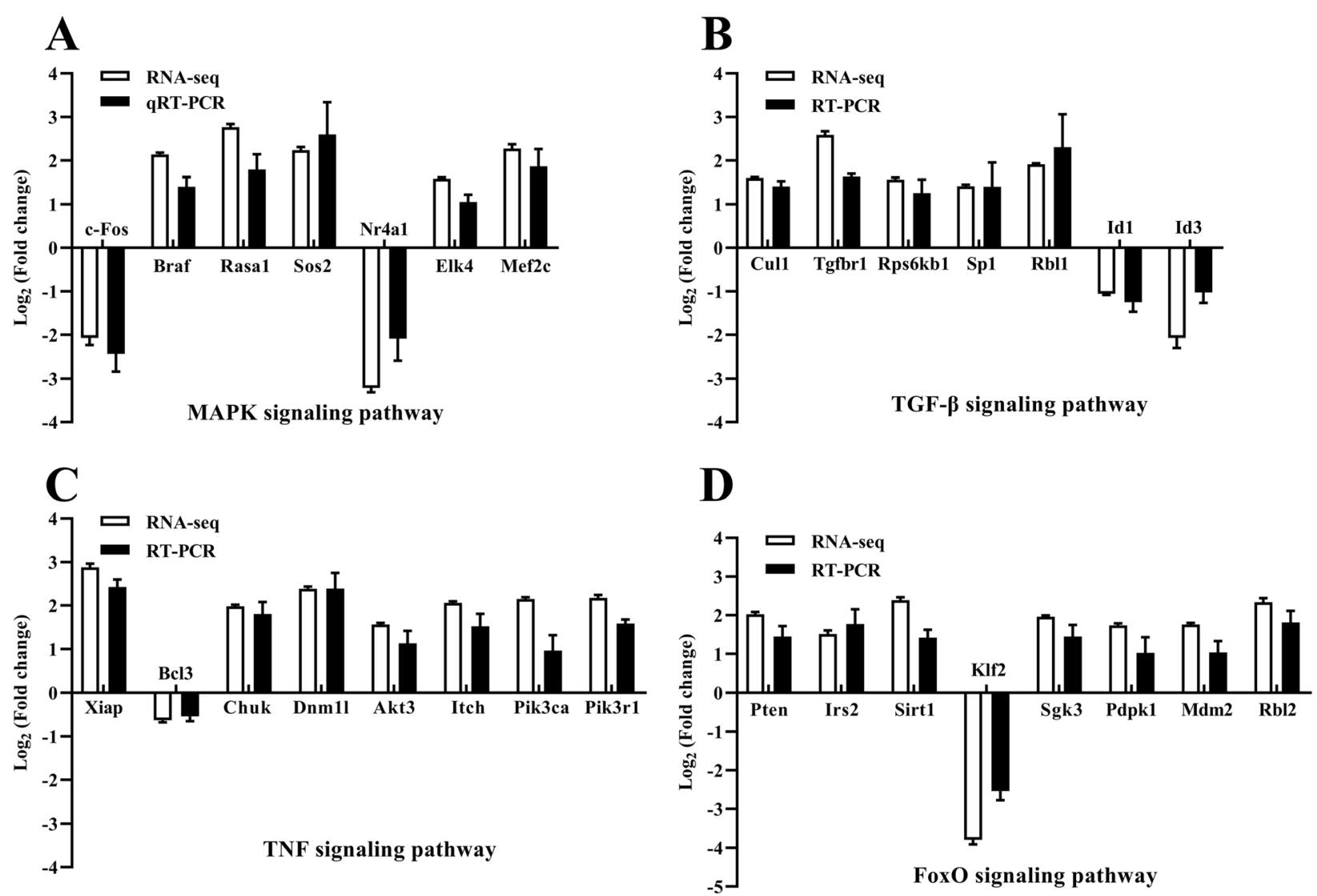

Fig. 10 qRT-PCR validation of expression levels of the overlapping DEGs from MAPK signaling pathway $\mathbf{a}$, TGF- $\beta$ signaling pathway $\mathbf{b}$, TNF signaling pathway c, and FoxO signaling pathway $\mathbf{d}$ in the C50336-VS-C50336::dam group. J774A.1 cells were pre-treated with LPS ( $1 \mu \mathrm{gg} / \mathrm{mL}, 5 \mathrm{~h}$ ) and then infected with C50336 or C50336::dam (cultured with IPTG) at an MOI of 20 for $4 \mathrm{~h}$. Each group comprised three independent replicates. The cells were then collected, and the total RNA was isolated for qRT-PCR. The mRNA expression level was normalized against the mouse GAPDH transcript. Data are presented as mean \pm SEM of $\log _{2}$ (fold change) of triplicate samples

increased phosphorylation level of Jnk in Damexpressing macrophages compared to those in negative lentivirus transduced cells and control cells. These results demonstrated that Dam could specifically enhance the NLRP3 inflammasome activation independently via promoting Jnk activation in macrophages.

\section{Discussion}

Inflammatory caspases are multi-functional proteins, and activation of caspases not only play an essential role in mediating host defense against infection by pathogens but are also indispensable for the regulation of tumor development, metabolic syndromes, autoinflammatory disease, tissue repair, and cell survival [25]. NLRC4 and NLRP3 inflammasomes can detect exogenous and endogenous molecules that serve as indicators of Salmonella infection. Inflammasome activation triggers the secretion of the proinflammatory cytokines IL-1 $\beta$ and IL-18, as well as rapid cell lysis. Intracellular Salmonella is then released into the extracellular space, which can be a double-edged sword for both the host and bacteria. Salmonella exposed to neutrophil-mediated killing is extremely fragile [26], but the interaction also provides an opportunity for Salmonella to invade the intestinal epithelium or access the liver and spleen, which may promote systemic infection [27]. Inflammasomes play a key and multilayered role at distinct stages of immune defense against Salmonella infection, although unexpected redundancy was found among NLRP3 and NLRC4 in vivo [16]. To further understand the complex interplay of detection and evasion between SE and the inflammasome, a transposon library based on SE strain C50336 was 


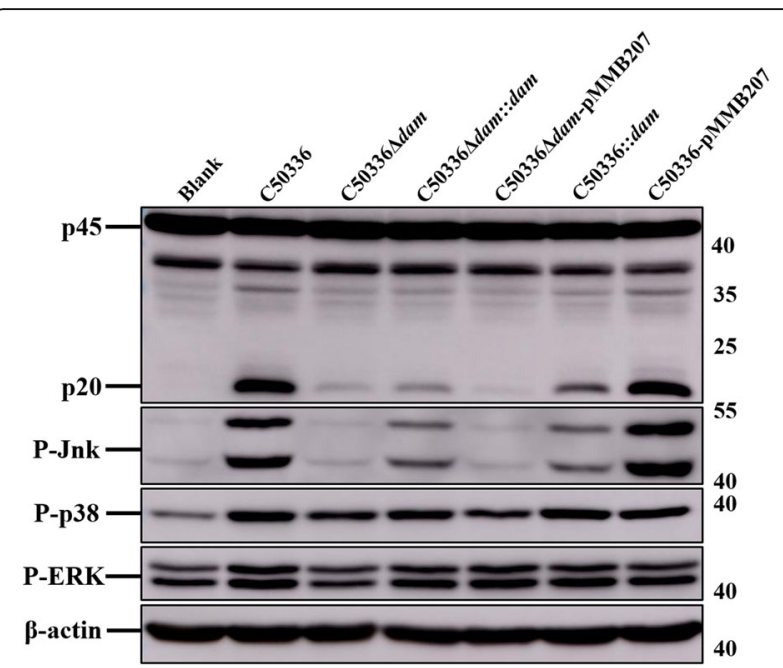

Fig. 11 The deletion of Dam blocked the Jnk pathway in infected J774A.1 cells. J774A.1 cells were pre-treated with LPS $(1 \mu \mathrm{g} / \mathrm{mL}, 5 \mathrm{~h})$

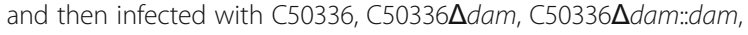
C50336 $\Delta$ dam-pMMB207, C50336::dam, or C50336-pMMB207 at an $\mathrm{MOl}$ of 20 for $4 \mathrm{~h}$, uninfected cells was used as a negative control (Blank). Bacteria bearing pMMB207 plasmids were cultured without IPTG. The activation of caspase-1, phosphorylated Jnk (P-Jnk), phosphorylated p38 (P-p38), and phosphorylated ERK1/2 (P-ERK1/2) were analyzed by immunoblotting. $\beta$-actin was blotted as a loading control. Molecular mass markers in $\mathrm{kDa}$ are indicated on the right. Original images of immunoblotting were shown in Fig. S7

generated and screened in this study. The mutant strains were identifed by increased or decreased LDH release compared to the WT C50336 parental strain after infection of J774A.1 cells in the first round of screening. Then, the candidate mutant strains were further rescreened for LDH release and activation of caspase- 1 in the second round screening. Four T3SS related genes (dam, invC, $\operatorname{prgH}$, and spaN) were identified after two rounds of screening, which the mutants of these four genes failed to activate the inflammasome indicating the importance of T3SS during modulating inflammasome activation. Our study offers new insights into understanding the interactions between SE and the inflammasome.

T3SS, as an important apparatus for inserting virulence factors into host cells, is often utilized by Salmonella to regulate the inflammasome responses. T3SS1 effector SopB was found to inhibit the activation of NLRC4 inflammasome during ST infection [19]. The SPI-2 T3SS is employed by ST to subvert human NLRP3 and NLRC4 inflammasome activation [28]. An essential component of T3SS is a highly conserved SPI-1 associated ATPase InvC in ST, which could couple with proton motive force to provide energy for the secretion process [29]. The deletion of $i n \nu C$ gene resulted in a significant decrease in secretion and translocation of effectors, which is required for Salmonella entry into epithelial cells [30]. Additionally, we also identified the spaN gene, which was known to be a target of the invasion secretion system [31]. The invasion-defective invC mutant of ST failed to secrete SpaN upon contact with live epithelial cells [32], which could explain why InvC and SpaN mutant strains are defective in activation of the inflammasome. In addition, InvC and SpaN were both reported to be essential for Salmonella virulence in a murine model [33]. The InvC deficient mutant of ST significantly reduced virulence in swine [34].

The needle complex (NC) is a structure of connected oligomeric rings assembled by T3SS that spans both membranes of bacteria and host cells for the delivery of virulence effectors [35]. The earliest step in NC morphogenesis is the association of $\operatorname{PrgH}$ and $\operatorname{PrgK}$ to form a base substructure and inner membrane rings. PrgH and PrgK are demonstrated to be the only T3SS components that are absolutely required for the formation of $\mathrm{NC}$ [36]. The previous studies showed that the NC rod proteins PrgI and PrgJ can be detected by NLRC4, and resulting in rapid activation of the inflammasome [14]. However, the rod proteins could not be detected in a correct location within the T3SS apparatus [11]. If T3SS exports excess rod monomers from the bacterial cytosol or if rod monomers slough into the interior channel of the needle apparatus, NLRC4 can respond to such inadvertent translocation of PrgI and PrgJ monomer [37]. In this study, the $\beta$-lactamase-based translocation assay indicated that the PrgH of SE could be transferred into host cells (Fig. 3). The transfer efficient of PrgH-TEM fusion protein was lower, and this is understandable considering that $\mathrm{PrgH}$ is a structural protein of $\mathrm{NC}$ and may also depend on inadvertent translocation, like PrgJ [11]. The persistent overexpression of PrgJ resulted in strong detection via NLRC4 and the complete clearance of ST in mice [38]. However, overexpression of $\mathrm{PrgH}$ induced by exogenous plasmid pMMB207 failed to trigger stronger expression of bioactive caspase- 1 and IL-1 $\beta$ in this work, indicating that NLRC4 could not directly detect PrgH to activate the inflammasome. None of the mutant strains

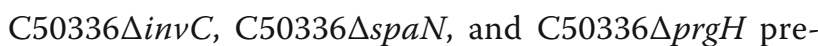
sented here decreased the mortality rate in the C57BL/6 mice model, in comparison with WT C50336. Whereas all of three gene deletion mutant strains were defective in inducing macrophage death in vitro, suggesting that the role of Salmonella SPI-1 T3SS in pathogenesis was different in vivo and in vitro. Besides, there may be other potential mechanisms for T3SS-defective SE mutants to induce activation of inflammasome in vivo. 


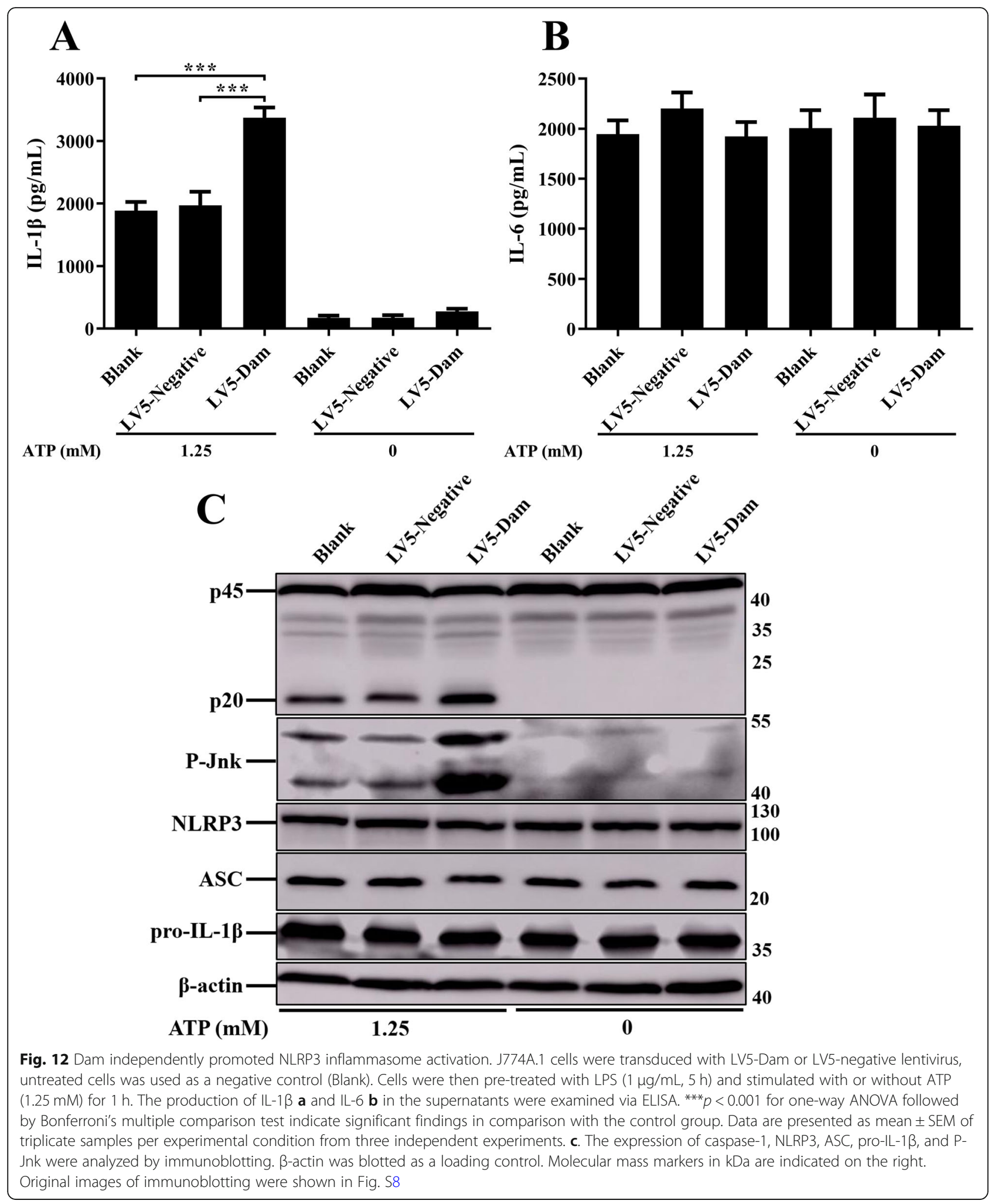

Crucial for DNA methylation, Dam modulates bacterial gene expression through N-6 methylation of adenosine residues in GATC sites [39]. While a broad range of processes are modulated by Dam, such as DNA replication and mismatch repair, chromosome segregation, surface protein expression, and transcription of insertion 
elements, lack of Dam does not impair bacterial viability $[22,40]$. In this study, a dam deletion mutant strain of SE was found to be defective in inducing activation of the inflammasome and pyroptosis, which was consistent with the findings of another study that found that IL-1 $\beta$ secretion is reduced in the absence of Dam compared with a WT ST strain [41]. Unlike the T3SS component deletion strains, dam mutations had an $\mathrm{LD}_{50}$ that was > $10^{4}$ higher than the WT parent strain in mice [22]. Similar results were found in this study. Salmonella Dam mutants were also attenuated for virulence in avian [42, 43], sheep [44], and bovine models [45, 46], which has been shown to confer cross-protective immunity to multiple Salmonella to prevent salmonellosis in animals and have been demonstrated as safe. Previous studies indicated that Dam is involved in the regulation of LPS synthesis, flagellar genes, fimbrial genes, and SPI-1 effector genes, and $\mathrm{prgH}$ also showed Dam-dependent regulation in both stationary-phase and static cultures [23], which seemed to be correlated with certain defects in the induction of pyroptosis and caspase-1 activation. Even then, dam mutants were able to persist in the liver, spleen, and lymph nodes of infected mice [47]. One likely explanation was that the reduced activation of the inflammasome induced by dam mutants resulted in Salmonella colonization in organs that could not be subjected to rapid and complete clearance, given that pyroptosis and secretion of IL-1 $\beta$ and IL-18 were an effective mechanism by which caspase-1 clears Salmonella [15]. A previous study showed that an ST strain that persistently expresses the flagellin protein FliC failed to evade NLRC4 detection and had been cleared efficiently [14].

Interestingly, the overexpression of Dam still prevented caspase- 1 activation and cell death, which was consistent with the findings that a Dam-overproducing ST strain was highly attenuated in mice [22]. Therefore, we speculated that the deletion and overexpression of Dam may have a similar effect on infected macrophages, and confirmed by RNA-seq and quantitative real-time PCR (qRT-PCR). In infected macrophages, the number of overlapping DEGs and enriched pathways were very high between the C50336-VSC50336 Adam and C50336-VS-C50336::dam groups, suggesting that homeostasis of dam expression was essential for Salmonella virulence and the ability to induce inflammasome activation. The MAPK signaling pathway [48], TGF- $\beta$ signaling pathway [49], TNF signaling pathway $[50,51]$, and FoxO signaling pathway [52] from overlapping enriched pathways were all reported to be related to the activation of inflammasome. The transcription regulator c-Fos plays an important role in regulating multiple signal pathways including MAPK and TNF [53]. A recent study reported that the c-Fos could bind to the promoter region of NLRP3 gene and positively regulate the inflammasome activation [54]. In this study, the expression levels of c-Fos induced by C50336 $\Delta$ dam and C50336::dam were both significantly lower than that induced by WT in J774A.1 cells (Figs. 9 and 10), which could explain the defective activation of caspase- 1 in both strains. Braf is an adaptor kinase in the MAPK pathway that transmits stimulatory signals of receptor binding growth factors [55]. Braf inhibitors were reported to upregulate the inflammasome activation and the production of IL-1 $\beta$ in dendritic cells [56]. Cullin1 (Cul1) was a key component of the Skp1-Cul1-F-box E3 ligase, which could bind and promote NLRP3 ubiquitination to repress systematic inflammasome activation [57]. Tgfbr1 and Pten were able to inhibit the expression of NLRP3, ASC, caspase- 1 , IL-1 $\beta$, and IL-18 in a mouse squamous cell carcinoma of the head and neck model [58]. Xlinked inhibitor of apoptosis protein (Xiap) was reported to restrict TNF- and RIP3-dependent cell death and inflammasome activation [50]. Besides, the IKK $\alpha$ (Chuk) was reported as a critical negative regulator of ASC-dependent inflammasomes, while the loss of IKK $\alpha$ kinase activity result in inflammasome hyperactivation [59]. In the FoxO pathway, the overexpression of Irs 2 was able to inhibit the IL- $1 \beta$ promoter activity [60]. The anti-inflammatory factor Sirtuin 1 (Sirt1) is a conserved NAD-dependent protein deacetylase, which has been demonstrated to attenuate the activation of NLRP3 inflammasome [61]. In this study, we observed that both C50336 ddam and C50336::dam could induce the high expression level of anti-inflammasome factors including Braf, Cul1, Tgfbr1, Pten, XIAP, Chuk, Irs2, and Sirt1 (Figs. 9 and 10), which could further explain why inflammasome could not be activated in the Dam deletion and overexpression strains.

A previous study demonstrated that apoptotic cell rates and NOS-2 and COX-2 expression were diminished in dam mutant strain-infected cells, coinciding with impaired activation of p38 and ERK MAPKs [62]. However, our result showed that the absence of Dam could not sufficiently inhibit the phosphorylation level of p38 and ERK1/2 for blocking the inflammasome activation. In addition, the Jnk pathway has been shown to regulate both at the priming stage and activation stage of NLRP3 inflammasome activation [63]. The phosphorylated Jnk is essentially required for ASC oligomerization, which is a critical step for NLRP3 inflammasome activation [64]. Recent studies reported that Jnk inhibitor could mediate Jnk inactivation, and further decrease the secretion of IL- $1 \beta$ and NLRP3 inflammasome activation [65]. In this study, both the deletion and overexpression of Dam decreased the phosphorylation level of Jnk, which could be related to the failure of activating inflammasome in SE infected 
macrophages, indicating that Jnk might become a target for SE in manipulating inflammasomes.

Moreover, the most surprising discovery in this study was that SE Dam specifically enhanced the activation of NLRP3 inflammasome independently via promoting Ink phosphorylation in the absence of bacteria. Unlike the T6SS effector EvpP of Edwardsiella tarda, which could suppress activation of the NLRP3 inflammasome independently by preventing Jnk activation in macrophages [66]. Dam was not a direct activator and was unable to activate the NLRP3 inflammasome without the help of ATP, indicating that the function of Dam expressed in host cells independently may not be the same as that in bacteria. It is accepted that the extracellular stimuli could promote NLRP3 inflammasome activation by inducing various molecular mechanisms including lysosomal permeability, potassium efflux, and mitochondrial reactive oxygen species (ROS) production $[67,68]$. The activation of Jnk pathway could enhance the activation of NLRP3 inflammasome through the production of MAPKs upstream signal ROS [65]. In this study, the expression level of Nr4a1 induced by C50336 was significantly higher than that induced by C50336 $\Delta$ dam, while the overexpression of Nr4a1 could enhance the production of ROS [69]. Jnk-mediated caspase activation has been known to enhance the cleavage of Xiap and disrupt its function [70]. Pten inactivation was associated with increased activity of the Jnk pathway in human prostate cancer [71]. The expression level of Sirt1 protein was reported to be downregulated via Jnk activation-mediated protein degradation [72]. In this study, the expression level of Xiap, Pten, and Sirt1 induced by WT C50336 was significantly lower than that induced by dam deletion mutant strain, which is consistent with studies mentioned above. The increasing of intracellular $\mathrm{Ca}^{2+}$ was essential for activation of NLRP3 inflammasome [73]. The ASC oligomerization requires the release of $\mathrm{Ca}^{2+}$, which could activate the TAK1-Jnk pathway by an upstream kinase TAK1, and trigger the activation of NLRP3 inflammasome [63]. Base on the findings above, we speculated that Dam might have a potential function in regulating $\mathrm{Ca}^{2+}$ release via Jnk pathway, which could subsequently influence the inflammasome activation.

\section{Conclusions}

In summary, we idenfied that Dam is a regulator of T3SS, which play an essential role in inducing inflammasome activation and pyroptosis during SE infection. We first described that the deletion and overexpression of Dam had a similar effect on inducing the macrophage death and secretion of inflammatory cytokines. The results of RNA-seq and qRT-PCR suggested that both C50336 Adam and C50336::dam were defective in inhibiting the expression of several anti-inflammasome factors (such as Braf, Cul1, Xiap, Pten, and Sirt1) compared to WT. In addition, both the absence and overexpression of Dam blocked the activation of Jnk pathway during SE infection. To our knowledge, it was the frst demonstration that Dam could enhance the activation of the NLRP3 inflammasome independently via promoting Ink phosphorylation in the absence of bacteria. Further research will focus on exploring more specific molecular mechanism of Dam regulates the activation of inflammasome and the effect of different expression levels of Dam on inflammasome activation. Collectively, our results provides a novel role of Dam in modulating inflammasome response and offers a new insights of the complex interplay between Dam and the inflammasome.

\section{Methods \\ Bacterial strains}

The wild-type SE strain C50336 was obtained from the National Institute for the Control of Pharmaceutical and Biological Products (Beijing, China). Escherichia coli X7213 $\lambda$ pir is stored in our laboratory. The bacterial strains and plasmids used in this study are listed in Table 1 . The gene deletion mutant strains were constructed by double exchange of homologous recombination as described previously [77]. The upstream and downstream fragments of target genes were amplified using PCR by employing the primers listed in Table 2. The PCR products were purified using the TaKaRa MiniBEST Agarose Gel DNA Extraction Kit Ver 4.0 (TaKaRa Biotechnology Co. Ltd., Dalian, China). The pDM4 plasmid was digested by restriction endonucleases $S a l$ I and $S a c$ I (TaKaRa). The purified plasmid and upstream and downstream fragments were fused using the ClonExpress MultiS One Step Cloning Kit (Vazyme Biotechnology Co. Ltd., Nanjing, China). The recombinant plasmids were transferred into X7213 $\lambda$ pir cells and sequenced. Single-crossover mutants were obtained by conjugal transfer of the recombinant suicide plasmids into C50336. Deletion mutants were screened on $15 \%$ sucrose Luria-Bertani (LB) plates. Construction of gene complementation strains and overexpression strains were performed as described previously [24]. Target genes were cloned into the low copy number plasmid pMMB207 by employing the ClonExpress II One Step Cloning Kit (Vazyme). The recombinant plasmids were mated from X7213 $\lambda$ pir into mutant or WT C50336 by conjugation. Chloramphenicol resistant transconjugants were selected, and the presence of the plasmids was confirmed by PCR analysis with flanking primers and sequencing. 
Table 1 Bacterial strains and plasmids used in this study

\begin{tabular}{|c|c|c|}
\hline Strain or plasmid & Relevant characteristics & Reference \\
\hline \multicolumn{3}{|l|}{ Escherichia coli } \\
\hline X7213 $\lambda$ pir & Host for $\pi$ requiring plasmids, conjugal donor & Labortaory collection \\
\hline X7213 גpir-pSC189 & X7213 $\lambda$ pir with pSC189, $\mathrm{Km}^{\mathrm{r}}, \mathrm{Cm}^{\mathrm{r}}$ & This study \\
\hline \multicolumn{3}{|l|}{ Salmonella Enteritidis } \\
\hline C50336 & Wild type & $\begin{array}{l}\text { Obtained from Chinese } \\
\text { National Institute for the } \\
\text { Control of Pharmaceutical } \\
\text { and Biological }\end{array}$ \\
\hline C50336 ddam & C50336, In-frame deletion in dam & This study \\
\hline C50336 $\operatorname{sinvC}$ & C50336, In-frame deletion in invC & This study \\
\hline C50336هhilD & C50336, In-frame deletion in hilD & This study \\
\hline C50336 $\triangle p r g H$ & C50336, In-frame deletion in prgH & This study \\
\hline C50336 $\Delta p a N$ & C50336, In-frame deletion in spaN & This study \\
\hline C50336 dam:: dam & C50336 $\triangle$ dam with pMMB207 expressing the dam gene, $\mathrm{Cm}^{r}$ & This study \\
\hline C50336 $\operatorname{invC::invC}$ & C50336 $\operatorname{inv} C$ with pMMB207 expressing the inv $C$ gene, $\mathrm{Cm}^{r}$ & This study \\
\hline C50336 hilD::hilD & C50336 $\operatorname{inv} C$ with pMMB207 expressing the hilD gene, $\mathrm{Cm}^{r}$ & This study \\
\hline C50336 $\operatorname{prgH::prgH}$ & C50336 $\Delta$ prgH with pMMB207 expressing the $\mathrm{prgH}$ gene, $\mathrm{Cm}^{r}$ & This study \\
\hline C50336 $\triangle$ spaN::spaN & C50336 dam with pMMB207 expressing the dam gene, $\mathrm{Cm}^{r}$ & This study \\
\hline C50336-pMMB207 & C50336 with pMMB207, $\mathrm{Cm}^{\mathrm{r}}$ & This study \\
\hline C50336::dam & C50336 with pMMB207 expressing the dam gene, $\mathrm{Cm}^{r}$ & This study \\
\hline C50336::prgH & C50336 with pMMB207 expressing the $\mathrm{prgH}$ gene, $\mathrm{Cm}^{\mathrm{r}}$ & This study \\
\hline C50336 $\Delta d a m-p M M B 207$ & C50336 $\triangle$ dam with pMMB207, $\mathrm{Cm}^{\mathrm{r}}$ & This study \\
\hline C50336 AprgH-pMMB207 & C50336 $\Delta$ prgH with pMMB207, $\mathrm{Cm}^{\mathrm{r}}$ & This study \\
\hline C50336-pCX340 & C50336 with pCX340, Tet ${ }^{r}$ & This study \\
\hline C50336-pCX340-dam & C50336 with pCX340 expressing the dam gene, Tet $^{r}$ & This study \\
\hline C50336-pCX340-invC & C50336 with pCX340 expressing the invC gene, Tet $^{r}$ & This study \\
\hline C50336-pCX340-prgH & C50336 with pCX340 expressing the prgH gene, Tet $^{r}$ & This study \\
\hline C50336-pCX340-spaN & C50336 with pCX340 expressing the dam gene, Tet $^{r}$ & This study \\
\hline \multicolumn{3}{|l|}{ Plasmids } \\
\hline pSC189 & Transposon delivery vector, $\mathrm{R} 6 \mathrm{~K}, \mathrm{Km}^{r}, \mathrm{Cm}^{r}$ & {$[74]$} \\
\hline pDM4 & Suicide vector, pir dependent, R6K, SacBR, $\mathrm{Cm}^{r}$ & [75] \\
\hline pMMB207 & IncQ lacl ${ }^{a} \Delta$ bla $P_{\text {tac-lac }} l a c Z a, C^{r}$ & {$[24]$} \\
\hline pMMB207-dam & pMMB207 derivative containing dam, $\mathrm{Cm}^{r}$ & This study \\
\hline pMMB207-invC & pMMB207 derivative containing invC, $\mathrm{Cm}^{r}$ & This study \\
\hline pMMB207-hilD & pMMB207 derivative containing hild, $\mathrm{Cm}^{\mathrm{r}}$ & This study \\
\hline pMMB207-prgH & pMMB207 derivative containing $\mathrm{prgH}_{1} \mathrm{Cm}^{\mathrm{r}}$ & This study \\
\hline pMMB207-spaN & pMMB207 derivative containing spaN, $\mathrm{Cm}^{r}$ & This study \\
\hline pCX340 & $\begin{array}{l}\text { pBR322 derivative, cloning vector used to fuse effectors to } \\
\text { TEM-1- } \beta \text {-lactamase, Tet }{ }^{r}\end{array}$ & {$[76]$} \\
\hline pCX340-dam & pCX340 derivative containing dam & This study \\
\hline pCX340-invC & pCX340 derivative containing invC & This study \\
\hline pCX340-prgH & $\mathrm{pCX} 340$ derivative containing prgH & This study \\
\hline pCX340-span & pCX340 derivative containing spaN & This study \\
\hline
\end{tabular}

The antibiotics as follows: kanamycin $\left(\mathrm{Km}^{r}\right), 100 \mu \mathrm{g} / \mathrm{mL}$; chloramphenicol $\left(\mathrm{Cm}^{r}\right), 25 \mu \mathrm{g} / \mathrm{mL}$; tetracycline (Tet $\left.{ }^{r}\right), 12.5 \mu \mathrm{g} / \mathrm{mL}$ 
Table 2 Primers used in this study

\begin{tabular}{|c|c|c|}
\hline Primer name & Primer sequence (5' to $\left.3^{\prime}\right)$ & Target \\
\hline$\overline{\mathrm{AB} 1}$ & GGCCACGCGTCGACTAGTACNNNNNNNNNNACGCC & For transposon insertion sequencing \\
\hline $\mathrm{AB} 2$ & GGCCACGCGTCGACTAGTACNNNNNNNNNNCCTGG & For transposon insertion sequencing \\
\hline $\mathrm{AB3}$ & GGCCACGCGTCGACTAGTACNNNNNNNNNNCCTCG & For transposon insertion sequencing \\
\hline ABS & GGCCACGCGTCGACTAGTAC & For transposon insertion sequencing \\
\hline SP1 & GCTGACCGCTTCCTCGTGCTTTACG & For transposon insertion sequencing \\
\hline SP2 & CATCGCCTTCTATCGCCTTCTTGAC & For transposon insertion sequencing \\
\hline pSC189-seq & CGCGAAGTTCCTATTCCGAAGTTCC & For transposon insertion sequencing \\
\hline pDM4-F & GGTGCTCCAGTGGCTTCTGTTTCTA & For deletion mutants \\
\hline $\mathrm{pDM} 4-R$ & CAGCAACTTAAATAGCCTCTAAT & For deletion mutants \\
\hline dam-up-F & $\begin{array}{l}\text { GAGCGGATAACAATTTGTGGAATCCCGGGAGACGCC } \\
\text { GAAAGCGACCACCACGACG }\end{array}$ & For dam deletion mutant \\
\hline dam-up-R & TTGAGAATTACATGCTGACTAACTAATTACACCTT & For dam deletion mutant \\
\hline dam-down-F & AGTCAGCATGTAATTCTCAAGGAGAAGCGGATGAA & For dam deletion mutant \\
\hline dam-down-R & $\begin{array}{l}\text { AGCGGAGTGTATATCAAGCTTATCGATACCCGATCTC } \\
\text { GCCGATATTGTTCACCTT }\end{array}$ & For dam deletion mutant \\
\hline dam-in-F & CGAGTGCCTTGTCGAACCTITGTG & For dam deletion mutant \\
\hline dam-in-R & ACAGAGCCAGCAGTTCGTCCACCTT & For dam deletion mutant \\
\hline dam-out-F & AACCACGACTGCGGAACCGAAGAAA & For dam deletion mutant \\
\hline dam-out-R & TCGGGTTTATCGAAAATTGCCGACC & For dam deletion mutant \\
\hline invC-up-F & $\begin{array}{l}\text { GAGCGGATAACAATTGTGGAATCCCGGGAGTCCTC } \\
\text { CTTACGTCTGTCGATGTCC }\end{array}$ & For invC deletion mutant \\
\hline invC-up-R & GCGAATGCATTCATCTCATTAGCGACCGACTAAAA & For invC deletion mutant \\
\hline invC-down-F & AATGAGATGAATGCATTCGCTGACCAGAATTAAAG & For invC deletion mutant \\
\hline invC-down-R & $\begin{array}{l}\text { AGCGGAGTGTATATCAAGCTTATCGATACCAATGCTT } \\
\text { CTGATAAACCGCCAACCT }\end{array}$ & For invC deletion mutant \\
\hline invC-in-F & GGGAACGCACCGTGTTGAGCCTTAT & For invC deletion mutant \\
\hline invC-in-R & CCAGGACGATATTCTCCCAAGTCAA & For invC deletion mutant \\
\hline $\operatorname{invC-out-F}$ & CAGTACCTTCCTCAGCCTTGACCCG & For invC deletion mutant \\
\hline invC-out-R & GCATTACGAAAGCATCGCCATAGTC & For invC deletion mutant \\
\hline hilD-up-F & $\begin{array}{l}\text { GAGCGGATAACAATTGTGGAATCCCGGGAGCTCAT } \\
\text { GGAGTATAATTTCGGTCGT }\end{array}$ & For hilD deletion mutant \\
\hline hilD-up-R & AAAAATGTTACATATTATCCCTTTGTTGATGTTAT & For hilD deletion mutant \\
\hline hilD-down-F & GGATAATATGTAACATTIITTGTATCTGTCACTTA & For hilD deletion mutant \\
\hline hilD-down-R & $\begin{array}{l}\text { AGCGGAGTGTATATCAAGCTTATCGATACCTGAAAGA } \\
\text { CTGTIIITAATGGTGCGC }\end{array}$ & For hilD deletion mutant \\
\hline hilD-in-F & GTCAGACTCAGCAGGTTACCATCAA & For hilD deletion mutant \\
\hline hilD-in-R & CATTATGGTTGCCTATGCGTAAAAG & For hilD deletion mutant \\
\hline hilD-out-F & TTCACCGACCTGTATTGGCGTATTT & For hilD deletion mutant \\
\hline hilD-out-R & TाTGGGGTGTAAATGCTGCTTATT & For hilD deletion mutant \\
\hline prgH-up-F & $\begin{array}{l}\text { GAGCGGATAACAATTTGTGGAATCCCGGGACACCAA } \\
\text { CATCCCAGGTTCGTCACAG }\end{array}$ & For prgH deletion mutant \\
\hline prgH-up-R & CGTTAAATTACATATATACTGTTAGCGATGTCTGT & For prgH deletion mutant \\
\hline prgH-down-F & AGTATATATGTAATTTAACGTAAATAAGGAAGTCA & For prgH deletion mutant \\
\hline prgH-down-R & $\begin{array}{l}\text { AGCGGAGTGTATATCAAGCTTATCGATACCTTCAACA } \\
\text { GCCCCGACTCCTITACGA }\end{array}$ & For prgH deletion mutant \\
\hline prgH-in-F & GTTGCTGCTCGTITGGGATAAGTG & For prgH deletion mutant \\
\hline prgH-in-R & GGCAAGGGTCATTACCAGCAGAAAG & For prgH deletion mutant \\
\hline
\end{tabular}


Table 2 Primers used in this study (Continued)

\begin{tabular}{|c|c|c|}
\hline Primer name & Primer sequence ( $5^{\prime}$ to $\left.3^{\prime}\right)$ & Target \\
\hline prgH-out-F & GAACGGCTGTGAGTTTCCATTGCTG & For prgH deletion mutant \\
\hline prgH-out-R & GACGGGCTCTGAGTATTTCTACATC & For prgH deletion mutant \\
\hline spaN-up-F & $\begin{array}{l}\text { GAGCGGATAACAATTTGTGGAATCCCGGGAATTGAC } \\
\text { TTGGGAGAATATCGTCCTG }\end{array}$ & For spaN deletion mutant \\
\hline spaN-up-R & AATGACATCACATTAAATTATCTCCTCTGACTCGG & For spaN deletion mutant \\
\hline spaN-down-F & TAATTTAATGTGATGTCATTGCGTGTGAGACAGAT & For spaN deletion mutant \\
\hline spaN-down-R & $\begin{array}{l}\text { AGCGGAGTGTATATCAAGCTTATCGATACCCGCACGG } \\
\text { GAAGTACGAATCAGGAGT }\end{array}$ & For spaN deletion mutant \\
\hline spaN-in-F & CGACTATGGCGATGCTTTCGTAATG & For spaN deletion mutant \\
\hline spaN-in-R & CAAACGATGTTCAACCTGCGTATTT & For spaN deletion mutant \\
\hline spaN-out-F & AAAGCGTAAGCCGCGTTITGGACA & For spaN deletion mutant \\
\hline spaN-out-R & CAATTGATTCAAGCCAGGCAGAGTT & For spaN deletion mutant \\
\hline pMMB207-F & CTCCCGTTCTGGATAATGTT & For complemented mutants \\
\hline pMMB207-R & GGCGTTTCACTTCTGAGTTCG & For complemented mutants \\
\hline pMMB207-dam-F & $\begin{array}{l}\text { AGCTCGGTACCCGGGGATCCTCTAGCTAAAGGAAGA } \\
\text { CGTTATGAAAAAAAATCGCGCTIIITGA }\end{array}$ & For complemented mutant of $\Delta d a m$ \\
\hline pMMB207-dam-R & $\begin{array}{l}\text { TCTCATCCGCCAAAACAGCCAAGCTTTATTTTCTTGCA } \\
\text { GGCGTTGCGACT }\end{array}$ & For complemented mutant of $\Delta d a m$ \\
\hline pMMB207-invC-F & $\begin{array}{l}\text { AGCTCGGTACCCGGGGATCCTCTAGCTAAAGGAAGA } \\
\text { CGTTATGAAAACACCTCGTTTACTGCAAT }\end{array}$ & For complemented mutant of $\triangle$ invC \\
\hline pMMB207-invC-R & $\begin{array}{l}\text { TCTCATCCGCCAAAACAGCCAAGCTTTAATTCTGGTC } \\
\text { AGCGAATGCATTC }\end{array}$ & For complemented mutant of $\triangle i n v C$ \\
\hline pMMB207-prgH-F & $\begin{array}{l}\text { AGCTCGGTACCCGGGGATCCTCTAGCTAAAGGAAGA } \\
\text { CGTTATGGAAACATCAAAAGAGAAGACGA }\end{array}$ & For complemented mutant of $\Delta p r g H$ \\
\hline pMMB207-prgH-R & $\begin{array}{l}\text { TCTCATCCGCCAAAACAGCCAAGCTITAAAGTGGGCT } \\
\text { TGGGAAATACCAA }\end{array}$ & For complemented mutant of $\Delta p r g H$ \\
\hline pMMB207-spaN-F & $\begin{array}{l}\text { AGCTCGGTACCCGGGGATCCTCTAGCTAAAGGAAGA } \\
\text { CGTTATGGGCGATGTGTCAGCTGTCAGTT }\end{array}$ & For complemented mutant of $\triangle$ spaN \\
\hline pMMB207-spaN-R & $\begin{array}{l}\text { TCTCATCCGCCAAAACAGCCAAGCTTCAGGCGTCATC } \\
\text { CTCCTCGCCAGAT }\end{array}$ & For complemented mutant of $\triangle$ spaN \\
\hline $\mathrm{pCX} 340-\mathrm{F}$ & AGACAATCTGTGTGGGCACTCGACC & For $\beta$-lactamase TEM-1 fusion plasmid \\
\hline $\mathrm{pC} \times 340-\mathrm{R}$ & TTCTGAGAATAGTGTATGCGGCGAC & For $\beta$-lactamase TEM-1 fusion plasmid \\
\hline $\mathrm{pCX} 340-d a m-\mathrm{F}$ & $\begin{array}{l}\text { AAGGAGGAATAACATATGATGAAAAAAAATCGCGCT } \\
\text { TाITGA }\end{array}$ & For $\beta$-lactamase TEM-1 fusion plasmid \\
\hline pCX340-dam-R & $\begin{array}{l}\text { GTGCGAATTCTCCGCGGAGGTACCTTTTCTTGCAGGC } \\
\text { GTTGCGACT }\end{array}$ & For $\beta$-lactamase TEM-1 fusion plasmid \\
\hline pCX340-invC-F & AAGGAGGAATAACATATGATGAAAACACCTCGTTAACTGCAAT & For $\beta$-lactamase TEM-1 fusion plasmid \\
\hline pCX340-invC-R & GTGCGAATTCTCCGCGGAGGTACCATTCTGGTCAGCGAATGCATTC & For $\beta$-lactamase TEM-1 fusion plasmid \\
\hline pCX340-prgH-F & AAGGAGGAATAACATATGATGGAAACATCAAAAGAGAAGACGA & For $\beta$-lactamase TEM-1 fusion plasmid \\
\hline pCX340-prgH-R & GTGCGAATTCTCCGCGGAGGTACCAAGTGGGCTTGGGAAATACCAA & For $\beta$-lactamase TEM-1 fusion plasmid \\
\hline pCX340-spaN-F & AAGGAGGAATAACATATGATGGGCGATGTGTCAGCTGTCAGTT & For $\beta$-lactamase TEM-1 fusion plasmid \\
\hline pCX340-spaN-R & GTGCGAATTCTCCGCGGAGGTACCGGCGTCATCCTCCTCGCCAGAT & For $\beta$-lactamase TEM-1 fusion plasmid \\
\hline
\end{tabular}

\section{Construction of transposon mutant library and transposon insertion sequencing}

Random transposition of TnpSC189 into the C50336 chromosome was achieved by using the delivery plasmid pSC189 [74]. For conjugation, the X7213
Apir donor strain bearing the plasmid pSC189 was cultivated in LB broth containing $50 \mu \mathrm{g} / \mathrm{mL}$ DAP (diaminopimelic acid) and $100 \mu \mathrm{g} / \mathrm{mL}$ kanamycin, while recipient strain C50336 was cultured in ordinary LB broth and grown until mid-logarithmic phase 
$\left(\mathrm{OD}_{600}=0.6\right)$. Equal volumes $(100 \mu \mathrm{L})$ of bacterial suspensions were mixed after two washes with fresh LB medium. The mixed suspension was plated on nitrocellulose filters placed on the surface of LB agar plates supplemented with DAP $(50 \mu \mathrm{g} / \mathrm{mL})$ and incubated for $12 \mathrm{~h}$ at $37^{\circ} \mathrm{C}$. The conjugation mixtures were then diluted with sterile phosphate-buffered saline (PBS) and plated on LB agar supplemented with kanamycin $(100 \mu \mathrm{g} / \mathrm{mL})$.

Two-round semi-arbitrary PCR was used to determine the location of the transposon insertion [78]. PrimeSTAR $^{\circ}$ Max DNA Polymerase (TaKaRa) was employed in a $10-\mu \mathrm{L}$ reaction volume consisting of $2 \times$ PrimeSTAR Max Premix $(5 \mu \mathrm{L}), 0.25 \mu \mathrm{M}$ of SP1 primer, $0.1 \mu \mathrm{M}$ of $\mathrm{AB} 1, \mathrm{AB} 2$, and $\mathrm{AB} 3$ primers (Table 2), and $1 \mu \mathrm{L}$ of an overnight LB-grown culture as the source of DNA. The first-round reaction conditions were as follows: 1 cycle of $95^{\circ} \mathrm{C}$ for $5 \mathrm{~min}$, 6 cycles of $95{ }^{\circ} \mathrm{C}$ for $30 \mathrm{~s}, 42-36{ }^{\circ} \mathrm{C}$ for $30 \mathrm{~s}\left(1{ }^{\circ} \mathrm{C}\right.$ reduction per cycle), and $72{ }^{\circ} \mathrm{C}$ for $3 \mathrm{~min}$, then 26 cycles of $95^{\circ} \mathrm{C}$ for $30 \mathrm{~s}, 58^{\circ} \mathrm{C}$ for $30 \mathrm{~s}$, and $72{ }^{\circ} \mathrm{C}$ for $3 \mathrm{~min}$, followed by $1 \mathrm{cycle}$ of $72^{\circ} \mathrm{C}$ for $10 \mathrm{~min}$. The second-round reaction was performed in a total volume of $30 \mu \mathrm{L}$ containing $15 \mu \mathrm{L}$ of $2 \times$ PrimeSTAR Max Premix, $0.25 \mu \mathrm{M}$ of SP2 and ABS primers (Table 2), with $2 \mu \mathrm{L}$ of the first-round reaction product as the source of DNA. The second-round PCR amplifications were performed as follows: 1 cycle of $95^{\circ} \mathrm{C}$ for $5 \mathrm{~min}, 30 \mathrm{cycles}$ of $95^{\circ} \mathrm{C}$ for $30 \mathrm{~s}, 64^{\circ} \mathrm{C}$ for $30 \mathrm{~s}$, and $72{ }^{\circ} \mathrm{C}$ for $3 \mathrm{~min}$, followed by 1 cycle of $72{ }^{\circ} \mathrm{C}$ for $10 \mathrm{~min}$. The second-round PCR products were sequenced using the pSC189-seq primer (Table 2) and the sequences were compared with the GenBank DNA sequence database using the BLASTX program.

\section{Mice and cell culture}

Specific pathogen-free (SPF) female C57BL/6 mice (age, 6-8 weeks; body weight, $20 \pm 2 \mathrm{~g}$ ) were obtained from the Comparative Medical Center of Yangzhou University (Yangzhou, China). All mice were bred under specific pathogen-free conditions, in the mouse isolators (Suzhou monkey animal experiment equipment Technology Co. Ltd., Suzhou, China). Five mice were raised in a cage, fed with pathogen-free diet and water. All animal experiments were approved by the Animal Welfare and Ethics Committees of Yangzhou University and complied with the guidelines of the Institutional Administrative Committee and Ethics Committee of Laboratory Animals (IACUC license number: YZUDWLL-201811-001). All animals were subjected to a clinical examination to assess their physical appearance and the normality of their behavior, and those presenting signs of disease were removed. All animals were humanely handled. For bone marrow preparations animals were sacrificed by cervical dislocation after anesthesia by intraperitoneal injection of $20 \%$ urethane (ethyl carbamate) solution. Animals used for the evaluation of bacterial virulence in this study were euthanized by $\mathrm{CO}_{2}$ delivery from a compressed $\mathrm{CO}_{2}$ gas cylinder directly in the mouse cages to reduce stress. Euthanasia was accomplished by slow exposure to increasing levels of $\mathrm{CO}_{2}$, replacing approximately $15-30 \%$ of the cage volume per minute, outside the mouse cages. Flow was kept for $2 \mathrm{~min}$ and the animals were maintained in the same cage for an additional $5 \mathrm{~min}$.

BMDMs are primary macrophages obtained from C57BL/6 mouse bone marrow of the tibia and femur as described previously [79]. Three mice were uesd for BMDM preparation in each individual experiment, three independent experiments were performed. Bone marrow cells were cultured at $37^{\circ} \mathrm{C}$ with $5 \% \mathrm{CO}_{2}$ in Dulbecco's modified Eagle's medium (DMEM, Gibco, Grand Island, NY, USA) supplemented with $10 \%(\mathrm{v} / \mathrm{v})$ fetal bovine serum (FBS, Gibco), $100 \mathrm{U} / \mathrm{mL}$ penicillin, $100 \mu \mathrm{g} / \mathrm{mL}$ streptomycin (Gibco), and $25 \mathrm{ng} / \mathrm{mL}$ macrophage colony-stimulating factor (M-CSF, PeproTech, Rocky Hill, NJ, USA). Fresh medium was added on day 3. Differentiated BMDMs were collected for experiments on day 6. J774A.1 and HeLa cells were were purchased from American Tissue Culture Collection (ATCC, Manassas, VA, USA) and cultured in complete DMEM containing $10 \%$ FBS, penicillin $(100 \mathrm{U} / \mathrm{mL})$, and streptomycin $(100 \mu \mathrm{g} / \mathrm{mL})$. Cell viability and number were determined by trypan blue exclusion assays.

\section{Salmonella infection}

Each single SE colony was cultured in LB medium, followed by overnight incubation at $37^{\circ} \mathrm{C}$ with shaking at $180 \mathrm{rpm}$. Overnight cultures were diluted 1:100 and cultured for another $3 \mathrm{~h}$ to an $\mathrm{OD}_{600}$ of 0.7 to induce SPI-1 expression [80]. J774A.1 cells or BMDMs were seeded into cell culture plates the day before infection. For inflammasome activation, the cells were washed with Dulbecco's PBS (DPBS, Gibco) and pre-treated with $1 \mu \mathrm{g} / \mathrm{mL}$ LPS (Sigma-Aldrich, St. Louis, MO, USA) diluted in Opti-MEM (Gibco) for $5 \mathrm{~h}$. Bacteria strains were washed twice with sterile PBS, added to the cells at an MOI of 20:1, and spun onto the cells at $1000 \mathrm{rpm}$ for 10 min. Cells were incubated at $37^{\circ} \mathrm{C}$ for $1 \mathrm{~h}$, subsequently washed twice, and incubated for an additional $3 \mathrm{~h}$ with Opti-MEM containing $50 \mu \mathrm{g} / \mathrm{mL}$ gentamicin.

In total, 70 female C57BL/6 mice (6-8 weeks old) were randomly assigned to seven groups $(n=10)$. Each group was intraperitoneally infected with $100 \mu \mathrm{L}$ of WT C50336 or gene deletion mutant strains diluted in PBS at a dose of $1 \times 10^{5} \mathrm{CFU}$ per mouse. The control mice 
received $100 \mu \mathrm{L}$ of $\mathrm{PBS}$ via the same route. All mice deaths were recorded over $14 \mathrm{dpc}$.

\section{Cytotoxicity assays and cytokine measurements}

J774A.1 cells or BMDMs were seeded at a concentration of $1 \times 10^{5}$ cells per well in 48-well plates. The cells were infected with SE strains as described above, and supernatants were harvested at $4 \mathrm{~h}$ after infection and centrifuged at $2000 \mathrm{rpm}$ for $5 \mathrm{~min}$ to remove cell debris. $\mathrm{LDH}$ release was quantified using the LDH Cytotoxicity Assay Kit (Beyotime Biotechnology Co. Ltd., Haimen, China) according to the manufacturer's instructions. Quantitative determination of pro-inflammatory cytokines IL- $1 \beta$ and IL-6 in supernatants were performed through an enzymelinked immunosorbent assay (ELISA) by employing Mouse IL-1 beta/IL-1F2 DuoSet ELISA and Mouse IL-6 DuoSet ELISA (R\&D Systems, Minneapolis, $\mathrm{MN}$, USA) according to the manufacturer's manual.

\section{Immunoblotting and antibodies}

J774A.1 cells or BMDMs were seeded into 12-well plates at a density of $5 \times 10^{5}$ cells per well and infected with bacteria as described above. After harvesting the supernatants, the remaining cells were directly lysed with $300 \mu \mathrm{L}$ cell lysis buffer per well for western and IP (Beyotime). For each single well, the supernatant and lysate were pooled separately. The mixtures were centrifuged at $2000 \mathrm{rpm}$ for $5 \mathrm{~min}$ to remove cell debris. An equal volume of methanol and a 0.25 volume of chloroform were added, and the solution was vortexed vigorously for $30 \mathrm{~s}$. The samples were centrifuged at 12000 $\mathrm{rpm}$ for $5 \mathrm{~min}$. The upper aqueous phase was removed, and an equal volume of methanol was added to each sample. The mixtures were centrifuged at $12000 \mathrm{rpm}$ for $5 \mathrm{~min}$ after vortexing for $10 \mathrm{~s}$. The protein pellets were dried at $55^{\circ} \mathrm{C}$ for $5-10 \mathrm{~min}$, resuspended with $40 \mu \mathrm{L}$ of $1 \times$ SDS-PAGE Sample Loading Buffer (Beyotime), and boiled for $10 \mathrm{~min}$ at $95^{\circ} \mathrm{C}$. The samples were loaded onto $15 \%$ Tris-glycine gels. The proteins were then transferred from the gels onto nitrocellulose membranes, which were blocked with blocking buffer (3\% nonfat dry milk in PBS) for $2 \mathrm{~h}$ at room temperature. The membranes were subsequently incubated on a rotator overnight at $4{ }^{\circ} \mathrm{C}$ with a primary antibody (diluted 1:1000 in blocking buffer). After 5 washes with PBST (0.05\% Tween 20 in PBS), the membranes were incubated at room temperature for $1.5 \mathrm{~h}$ with a secondary antibody diluted 1:5000 in blocking buffer. Images of antibody reactions with an ECL chemiluminescence substrate (Thermo Scientific, Waltham, MA, USA) were acquired using an Amersham Imager 600 Imaging System (GE Healthcare Life Sciences, Pittsburgh, PA, USA).
The primary antibodies used in this study were as follows: anti-caspase-1 p20 antibody (AG-20B-0042, AdipoGen, San Diego, CA, USA), anti-NLRP3/NALP3 antibody (AG-20B-0014, AdipoGen), anti-NLRC4 antibody (ab201792, Abcam, Cambridge, UK), anti-ASC/ TMS1 antibody (67824S, Cell Signaling Technology, Danvers, MA, USA), anti-IL-1 $\beta$ antibody (12507S, Cell Signaling Technology), anti- $\beta$-actin antibody (A5441, Sigma-Aldrich), anti-Phospho-SAPK/Jnk antibody (4671S, Cell Signaling Technology), anti-Phospho-p44/42 MAPK (ERK1/2) antibody (4377S, Cell Signaling Technology), and anti-Phospho-p38 MAPK antibody (9215S, Cell Signaling Technology). The secondary antibodies were goat anti-mouse IgG-HRP (401,215, Sigma-Aldrich) and goat anti-rabbit IgG-HRP (BS13278, Bioworld Technology, Bloomington, MN, USA).

\section{Protein translocation assays}

Plasmid pCX340 was used for a TEM-1 $\beta$-lactamase fusion protein FRET assay as described previously [76]. The target genes were amplified from the genome of wild-type C50336 and then ligated into the Nde I and Kpn I restriction sites in the multiple cloning region of pCX340 using the ClonExpress II One Step Cloning Kit (Vazyme). All recombinant plasmids were transferred into C50336 by electroporation. Overnight bacterial cultures were diluted to $1: 100$ in LB broth supplemented with $12.5 \mu \mathrm{g} / \mathrm{mL}$ tetracycline for $3 \mathrm{~h}$ and induced with 1 $\mathrm{mM}$ IPTG for another $3 \mathrm{~h}$.

HeLa cells were trypsinized and seeded in black, clearbottomed 24-well plates (Cellvis, Mountain View, CA, USA) at $2 \times 10^{5}$ cells per well. Bacterial strains bearing plasmid pCX340 were washed twice with DMEM, added to the cells at an MOI of 100:1, and spun onto the cells at $1000 \mathrm{rpm}$ for $10 \mathrm{~min}$. The cells were incubated for $3 \mathrm{~h}$, subsequently washed 4 times, and incubated for an additional $4 \mathrm{~h}$ with DMEM. The cells were washed with DMEM and covered with $300 \mu \mathrm{L}$ DMEM plus $60 \mu \mathrm{L}$ of $6 \times \mathrm{CCF} 2 / \mathrm{AM}$ solution freshly prepared with the CCF2/ AM loading kit (CCF2/AM final concentration, $1 \mu \mathrm{M}$; Invitrogen, Carlsbad, CA, USA). The plates were incubated for $2 \mathrm{~h}$ at room temperature, and images were acquired using a Leica confocal microscope (Leica Microsystems, Wetzlar, Germany). The appropriate filters were selected to allow for excitation of coumarin $(\sim 410 \mathrm{~nm})$ and detection of blue coumarin $(\sim 450 \mathrm{~nm})$ and green fluorescein $(\sim 520 \mathrm{~nm})$ emissions, enabling the simultaneous observation of green fluorescence emitted by the CCF2 substrate and blue fluorescence emitted by the cleaved CCF2 product. Translocation of $\beta$-lactamase fusions into CCF2-loaded cells was determined by counting the number of blue fluorescent cells in the images. Cells that did not exhibit secretion of TEM fusions appeared green. For a particular cell well from three 
separate experiments, six pictures were taken, and an average of 1200-2000 cells were counted. Each picture was considered an independent observation and used to calculate the percentage of blue fluorescent cells.

\section{Lentivirus infection assays}

Lentiviral vectors pGLV5-dam (EF-1aF/GFP\&Puro) and pGLV5-dam-His (EF-1aF/GFP\&Puro) for the Dam gene encoding a GFP sequence were designed, constructed, amplified, and purified by GenePharma (Shanghai, China). The packaging, collection, and titer determination of the lentivirus were also conducted by GenePharma. In general, $293 \mathrm{~T}$ producer cells were transfected with optimized packaging plasmids (pGag/ Pol, pRev, and pVSV-G) along with lentiviral vectors expressing Dam or Dam-His constructs by lipofectamine. Six hours post-transfection, the transfection mix was replaced with fresh DMEM containing $10 \%$ FBS. The virus-containing supernatant was harvested $72 \mathrm{~h}$ post-transfection, centrifuged at $4{ }^{\circ} \mathrm{C}$ and 4000 rpm for $4 \mathrm{~min}$, filtered through a $0.45 \mu \mathrm{m}$ filter (Millipore, Burlington, MA, USA), and centrifuged at $4{ }^{\circ} \mathrm{C}$ and $20,000 \mathrm{rpm}$ for $2 \mathrm{~h}$. The lentivirus particles were titrated by adding serial dilutions to fresh $293 \mathrm{~T}$ cells and assessed using GFP expression after $72 \mathrm{~h}$. The viral titers of approximately $1 \times 10^{9}$ infectious units/ $\mathrm{mL}$ were obtained and stored at $-80{ }^{\circ} \mathrm{C}$ before infection. The negative control lentivirus $\mathrm{Lv}-\mathrm{NC}\left(10^{9} \mathrm{TU} /\right.$ $\mathrm{mL}$ ) was also provided by GenePharma.

J774A.1 cells were seeded into 12 -well plates at a density of $1 \times 10^{5}$ cells per well. A $100 \mu \mathrm{L}$ volume of lentivirus was mixed with $400 \mu \mathrm{L}$ of complete DMEM, and polybrene (GenePharma) was added to a final concentration of $5 \mu \mathrm{g} / \mathrm{mL}$. The cells were incubated at $37^{\circ} \mathrm{C}$ for $24 \mathrm{~h}$, the medium was removed, and the cells were cultured in $500 \mu \mathrm{L}$ of complete DMEM for another $48 \mathrm{~h}$. The efficiency of lentivirus infection was evaluated by detection of GFP fluorescence. The cells were pretreated with LPS as described above and stimulated with $1.25 \mathrm{mM}$ ATP (Sigma) diluted in Opti-MEM (Gibco) for $1 \mathrm{~h}$. Then supernatants and cell lysates were collected for immunoblotting or ELISA as described above.

\section{RNA sequencing}

Overnight cultures of the wild-type strain C50336, gene deletion mutant strain C50336 $\Delta$ dam, and overexpression strain C50336::dam were diluted to $1: 100$ in LB broth and cultured to logarithmic phase $\left(\mathrm{OD}_{600}=0.7\right)$. J774A.1 cells were seeded at a density of $5 \times 10^{6}$ cells per $10-\mathrm{cm}$ dish. The cells were pre-treated with LPS and infected with SE strains as described above. Each group comprised three independent replicates. The cells were then collected with $1 \mathrm{~mL}$ Trizol (Ambion, Carlsbad, CA, USA) and sent to GENEWIZ (Suzhou,
China) for analysis. The total RNA was isolated, purified, and quantified by GENEWIZ. The eukaryotic transcriptome libraries were pooled and sequenced on an Illumina platform (Illumina, San Diego, CA, USA). The subsequent procedures and statistical analyses were conducted by GENEWIZ as previously described [81]. All sequences were deposited at NCBI Sequence Read Archive (SRA) with accession number SRP253144.

\section{qRT-PCR analysis}

J774A.1 cells were seeded into 12 -well plates at a density of $5 \times 10^{5}$ cells per well and infected with WT C50336, dam deletion mutant, complementation, and overexpression strains as described above. After infection for $4 \mathrm{~h}$, cells were harvested and total RNA was extracted using E.Z.N.A. ${ }^{\mathrm{m}}$ Total RNA Kit I (Omega Bio-tek, Norcross, GA, USA) by following the manufacturer's instructions. RNase-free DNase I (TaKaRa) was used to remove contaminating DNA in purified total RNA, in accordance with the manufacturer's instructions. RNA of the infected cells were quantified using One drop ${ }^{\mathrm{Tm}}$ spectrophotometer (Wins Technology Co. Ltd., Nanjing, China). PrimeScript RT Reagent Kit (TaKaRa) was used to reverse transcribe total RNA into cDNA. Reaction was performed in a total volume of $20 \mu \mathrm{L}$, containing $1 \mu \mathrm{g}$ of total RNA, $1 \mu \mathrm{L}$ of PrimeScript RT Enzyme Mix I, $4 \mu \mathrm{L}$ of RT Primer Mix, $4 \mu \mathrm{L}$ of $5 \times$ PrimeScript Buffer 2. The mixture was incubated at $37^{\circ} \mathrm{C}$ for $15 \mathrm{~min}$, followed by incubation at $85^{\circ} \mathrm{C}$ for $5 \mathrm{~s}$, subsequently stored at $-20^{\circ} \mathrm{C}$ until further use.

The Applied Biosystems QuantStudio 6 Flex RealTime PCR System (Applied Biosystems, Foster City, CA, USA) was used to measure the mRNA expression levels of c-Fos, Braf, Rasa1, Sos2, Nr4a1, Elk4, Mef2c, Cul1, Tgfbr1, Rps6kb1, Rbl1, Id1, Id3, Xiap, Bcl3, Chuk, Dnm1l, Akt3, Itch, Pik3ca, Pik3r1, Pten, Irs2, Sirt1, Klf2, Sgk3, Pdpk1, Mdm2, and Rbl2 as well as of the internal control gene, mouse GAPDH. Primers were designed using Primer Express software v3.0 (Applied Biosystems, Carlsbad, CA, USA) and were listed in Table 3. The qRT-PCR reaction was performed in a total volume of $20 \mu \mathrm{L}$, containing $200 \mathrm{ng}$ of $\mathrm{cDNA}, 10 \mu \mathrm{L}$ of $2 \times$ SYBR Green Master Mix (TaKaRa), $0.6 \mu \mathrm{L}$ each of $10 \mu \mathrm{M}$ forward and reverse primers, and $6.8 \mu \mathrm{L}$ RNase-free water. The comparative threshold cycle $\left(2^{-\Delta \Delta C(T)}\right.$ method) was used to calculate relative concentrations. All qRT-PCR reactions were performed in triplicates.

\section{Statistical analysis}

The Z score was calculated for each well in a 48-well plate as described previously [82]. For a given well, the $\mathrm{Z}$ score was calculated by subtracting the mean value of the wells on that plate from the value of the given well and dividing by the standard deviation value for all of 
Table 3 Primers used in qRT-PCR

\begin{tabular}{|c|c|c|c|c|c|}
\hline Primer name & Primer sequence $\left(5^{\prime}\right.$ to $\left.3^{\prime}\right)$ & Target & Primer name & Primer sequence $\left(5^{\prime}\right.$ to $\left.3^{\prime}\right)$ & Target \\
\hline c-Fos-F & CTCCCGTGGTCACCTGTACT & Detection of mRNA & Pten-F & CATAACGATGGCTGTGGTTG & Detection of mRNA \\
\hline c-Fos-R & TTGCCTTCTCTGACTGCTCA & Detection of mRNA & Pten-R & CGGGGTAAGGCTGTITTACA & Detection of mRNA \\
\hline Braf-F & GTAGCGCCTGTTCAGTCCTC & Detection of mRNA & Irs2-F & GTAGTTCAGGTCGCCTCTGC & Detection of mRNA \\
\hline Braf-R & GAGCAGCCTGAGTGGTTAGG & Detection of mRNA & Irs2-R & CAGCTATTGGGACCACCACT & Detection of mRNA \\
\hline Rasal-F & CGGGGTCCTITGTACTITCA & Detection of mRNA & Sirt1-F & AGTTCCAGCCGTCTCTGTGT & Detection of mRNA \\
\hline Rasa1-R & TGGTGGTGCAACTGGATAGA & Detection of mRNA & Sirt1-R & CTCCACGAACAGCTTCACAA & Detection of mRNA \\
\hline Sos $2-F$ & CAGTCCTCTTGCCACACTCA & Detection of mRNA & $\mathrm{KIf} 2-\mathrm{F}$ & GCCTGTGGGTTCGCTATAAA & Detection of mRNA \\
\hline Sos2-R & GTGGAATAGCAGGAGGGTCA & Detection of mRNA & $\mathrm{KIf} 2-\mathrm{R}$ & AAGGAATGGTCAGCCACATC & Detection of mRNA \\
\hline Nr4a1-F & CTTGAGTTCGGCAAGCCTAC & Detection of mRNA & Sgk3-F & ATCCAGATGTCCGAGCATTC & Detection of mRNA \\
\hline Nr4a1-R & CGAGGATGAGGAAGAAGACG & Detection of mRNA & Sgk3-R & GAAGAACCTTGCCAAAGCTG & Detection of mRNA \\
\hline Elk4-F & AGCTITGCCAGAAAAGGACA & Detection of mRNA & Pdpk1-F & GGTCCAGTGGATAAGCGAAA & Detection of mRNA \\
\hline Elk4-R & TGGTGTAAGAGACGCTGTCG & Detection of mRNA & Pdpk1-R & TTCTGCACCACTTGTGAGC & Detection of mRNA \\
\hline Mef2c-F & ACGCCTGTCACCTAACATCC & Detection of mRNA & Mdm2-F & TGCAAGCACCTCACAGATTC & Detection of mRNA \\
\hline Mef2c-R & AGCTCTCAAACGCCACACTT & Detection of mRNA & Mdm2-R & ACACAATGTGCTGCTGCTTC & Detection of mRNA \\
\hline
\end{tabular}

Cul1-F GAATTGGGGCTGAATGAAGA

Cul1-R AACTCTCCGCTGTTCCTCAA

Tgfbr1-F GGCGAAGGCATTACAGTGTT

Tgfbr1-R TGCACATACAAATGGCCTGT

Rps6kb1-F GCTGTGGATTGGTGGAGTT

Rps6kb1-R GCTTGGACTTCTCCAGCATC

Sp1-F TGCAGCAGAATTGAGTCACC

Sp1-R CACAACATACTGCCCACCAG

Rbl1-F AAACCTTGCACCACAAGTACG

Rbl1-R GCACAGGAGACATTTGATCATT

ld1-F CCAGTGGGTAGAGGGTTTGA

Id1-R AGAAATCCGAGAAGCACGAA

Id3-F

ACTCAGCTTAGCCAGGTGGA

Id3-R

Xiap-F

Xiap-R

$\mathrm{BCl} 3-\mathrm{F}$

$B C \mid 3-R$

Chuk-F

Chuk-R

Dnm1l-F

GTCAGTGGCAAAAGCTCCTC

Dnm1l-R

Akt3-F

Akt3-R

Itch-F

Itch-R

Pik3ca-F

TTGGAACATGGACATCCTCA

TGCCCCTTCTCATCCAATAG

TTACTCTACCCCGACGATGG

CCAAGCTTGAAAAGGCTGAG

TGGAGCCTACGAAGCTGTTT

CCCTCATTAGTTGCGGTGTT

Pik3ca-R

Pik3r1-F

Pik3r1-R
ACCCGGAGACCTCTCATTCT

GGCGAGAAAACCTTGAGATG

GAAACTGGCCACTTCTGCTC

ACTGAGGTGTGGTGGAGACC

\section{CATGTGGTITGGCAGTTTG}

TTGTAAGGTGGGAGGTCCAG

ACTGTTCAGAGAGGCCAGGA

CGGTTGCCTACTGGTTCAAT

GCGTGACATGTAGGCTCTCA

CAGTTCCTTGGCTTTGCTC
Detection of mRNA

Detection of mRNA

Detection of mRNA

Detection of mRNA

Detection of mRNA

Detection of mRNA

Detection of mRNA

Detection of mRNA

Detection of mRNA

Detection of mRNA

Detection of mRNA

Detection of mRNA

Detection of mRNA

Detection of mRNA

Detection of mRNA

Detection of mRNA

Detection of mRNA

Detection of mRNA

Detection of mRNA

Detection of mRNA

Detection of mRNA

Detection of mRNA

Detection of mRNA

Detection of mRNA

Detection of mRNA

Detection of mRNA

Detection of mRNA

Detection of mRNA

Detection of mRNA
Detection of mRNA
Table 3 Primers used in qRT-PCR (Continued)

the plate wells. A Z score $\leq-2$ or $\geq 2$ was considered significant. All data are presented as mean \pm standard error (SEM) of triplicate samples per experimental condition from three independent experiments using GraphPad Prism 5 software (La Jolla, USA). To detect significant differences between experimental groups, an one-way analysis of variance (ANOVA) followed by Bonferroni's multiple comparison test were conducted. Statistical significance was determined at $p$ values of $<0.05\left({ }^{*}\right)$, $<$ $\left.0.011^{(* *)}\right)$, or $<0.001^{(* * *)}$.

\section{Supplementary information}

Supplementary information accompanies this paper at https://doi.org/10. 1186/s12866-020-01919-z.

Additional file 1: Figure S1. Growth curves of dam, invC, hilD, prgH, and spaN gene deletion mutants, complementation, and overexpression strains. Figure S2. Two rounds of screening to identify the genes involved in regulating inflammasome activation in vitro (original images of immunoblotting). Figure S3. Deletion mutants of dam, invC, prgH, and spaN failed to induce inflammasome activation (original images of immunoblotting). Figure S4. Deletion of $\mathrm{prgH}$ did not influence the synthesis of inflammasome components (original images of immunoblotting). Figure S5. Overexpression of Dam inhibited inflammasome activation (original images of immunoblotting). Figure S6. The ability of the dam complementation strain and overexpression strain cultured without IPTG to activate the inflammasome was improved (original images of immunoblotting). Figure S7. The deletion of Dam blocked the Jnk pathway in infected J774A.1 cells (original images of immunoblotting). Figure S8. Dam independently promoted NLRP3 inflammasome activation (original images of immunoblotting).

\section{Abbreviations}

SE: Salmonella Enteritidis; SPI: Salmonella pathogenicity island; T3SS: type III secretion system; SCV: Salmonella-containing vacuole; PRRs: pattern recognition receptors; NLRs: Nod-like receptors; AIM2: Melanoma 2; ASC: Apoptosis-associated speck-like proteins containing caspase recruitment domains; IL-1 $\beta$ : Interleukin-1 $\beta$; WT: Wild type; Dam: DNA adenine methylase; LDH: Lactate dehydrogenase; DEGs: Differentially expressed genes; LB: LuriaBertani; DAP: Diaminopimelic acid; PBS: Phosphate-buffered saline; 
DMEM: Dulbecco's modified Eagle's medium; FBS: Fetal bovine serum; MCSF: Macrophage colony-stimulating factor; DPBS: Dulbecco's phosphatebuffered saline; dpc: Days post-challenge; ELISA: Enzyme-linked immunosorbent assay; FRET: Fluorescence resonance energy transfer; $\mathrm{Km}^{r}$ : Kanamycin; $\mathrm{Cm}^{r}$ : Chloramphenicol; Tet': Tetracycline; MAPK: Mitogenactivated protein kinase; KEGG: Kyoto Encyclopedia of Genes and Genomes; TNF: Tumor necrosis factor; qRT-PCR: Quantitative real-time PCR; GAPD H: Glyceraldehyde-3-phosphate dehydrogenase; Ink: C-Jun N-terminal kinase; ERK1/2: Extracellular regulated protein kinases 1/2; GFP: Green fluorescent protein; ATP: Adenosine triphosphate; FoxO: Forkhead box, sub-group O; Xiap: X-linked inhibitor of apoptosis protein; ROS: Reactive oxygen species

\section{Acknowledgments}

The authors sincerely thank the members of the Jiangsu Key Laboratory of Zoonosis who participated in this work. We are especially grateful to Dr. Tang yuanyue for providing English language editing service. We thank editor Brenda K, Wordvice (wordvice.cn), for editing the English text of a draft of this manuscript.

\section{Authors' contributions}

$Y G, D G$, and ZP conceived of and designed the experiments. YG, DG, and TH performed the experiments and analyzed the experimental results. $L C, X Z$, $Y Z$, and $\mathrm{KW}$ analyzed experiment performance. $\mathrm{YG}, \mathrm{XK}$, and $\mathrm{CM}$ analyzed and interpreted all of the data. YG performed the statistical analyse and wrote manuscript. XJ and ZP did the supervised study. All authors read and approved the manuscript.

\section{Funding}

This work was funded by the National Natural Science Foundation of China [grant number 31972685, 31920103015]; the China Postdoctoral Science Foundation [grant number 2018 M642333]; the Yangzhou University Science and Technology Innovation Team (2016); and the Priority Academic Program Development of Jiangsu Higher Education Institutions (PAPD). The funding entities had no role in design of the study, collection, analysis or interpretation of data, or writing of the manuscript.

\section{Availability of data and materials}

All data generated or analyzed during this study are included in this published article. Any additional information will be made available from the corresponding author on reasonable request. RNA sequences were deposited at NCBI Sequence Read Archive (SRA) with accession number SRP253144.

\section{Ethics approval and consent to participate}

This manuscript reports data obtained in the mouse. All mice were bred under specific pathogen-free conditions, in the mouse isolators, fed with pathogen-free diet and water. All animal experiments were approved by the Animal Welfare and Ethics Committees of Yangzhou University and complied with the guidelines of the Institutional Administrative Committee and Ethics Committee of Laboratory Animals (IACUC license number: YZUDWLL-201811001). All animals were humanely handled.

\section{Consent for publication}

Not applicable.

\section{Competing interests}

The authors declare that they have no competing interests.

\footnotetext{
Author details

'Jiangsu Key Laboratory of Zoonosis, Yangzhou University, Yangzhou 225009, Jiangsu, China. ${ }^{2}$ Jiangsu Co-innovation Center for Prevention and Control of Important Animal Infectious Diseases and Zoonoses, Yangzhou University, Yangzhou 225009, Jiangsu, China. ${ }^{3}$ Key Laboratory of Prevention and Control of Biological Hazard Factors (Animal Origin) for Agrifood Safety and Quality, Ministry of A griculture of China, Yangzhou University, Yangzhou, Jiangsu, China. ${ }^{4}$ Joint International Research Laboratory of Agriculture and Agri-product Safety of the Ministry of Education, Yangzhou University, Yangzhou, Jiangsu, China.
}

Received: 8 April 2020 Accepted: 21 July 2020

Published online: 28 July 2020

\section{References}

1. Hannemann S, Galan JE. Salmonella enterica serovar-specific transcriptional reprogramming of infected cells. PLoS Pathog. 2017;13(7):e1006532. https:// doi.org/10.1371/journal.ppat.1006532.

2. Fink SL, Cookson BT. Pyroptosis and host cell death responses during Salmonella infection. Cell Microbiol. 2007;9(11):2562-70. https://doi.org/10. 1111/j.1462-5822.2007.01036.x.

3. Rodrigue DC, Tauxe RV, Rowe B. International increase in Salmonella enteritidis: a new pandemic? Epidemiol Infect. 1990;105(1):21-7. https://doi. org/10.1017/s0950268800047609.

4. Holtby I, Tebbutt GM, Anwar S, Aislabie J, Bell V, Flowers W, et al. Two separate outbreaks of Salmonella enteritidis phage type $14 \mathrm{~b}$ food poisoning linked to the consumption of the same type of frozen food. Public Health. 2006;120(9):817-23. https://doi.org/10.1016/j.puhe.2006.05.010.

5. Chai SJ, White PL, Lathrop SL, Solghan SM, Medus C, McGlinchey BM, et al. Salmonella enterica serotype Enteritidis: increasing incidence of domestically acquired infections. Clin Infect Dis. 2012;54(Suppl 5):S488-97. https://doi.org/10.1093/cid/cis231.

6. Monack DM, Mueller A, Falkow S. Persistent bacterial infections: the interface of the pathogen and the host immune system. Nat Rev Microbiol. 2004;2(9):747-65. https://doi.org/10.1038/nrmicro955.

7. Jones BD, Falkow S. Salmonellosis: host immune responses and bacterial virulence determinants. Annu Rev Immunol. 1996;14:533-61. https://doi.org/ 10.1146/annurev.immunol.14.1.533.

8. Beuzon CR, Meresse S, Unsworth KE, Ruiz-Albert J, Garvis S, Waterman SR, et al. Salmonella maintains the integrity of its intracellular vacuole through the action of SifA. EMBO J. 2000;19(13):3235-49. https://doi.org/10.1093/ emboj/19.13.3235.

9. Crowley SM, Knodler LA, Vallance BA. Salmonella and the Inflammasome: Battle for intracellular dominance. Curr Top Microbiol Immunol. 2016;397: 43-67. https://doi.org/10.1007/978-3-319-41171-2_3.

10. Broz P, Dixit VM. Inflammasomes: mechanism of assembly, regulation and signalling. Nat Rev Immunol. 2016;16(7):407-20. https://doi.org/10.1038/nri. 2016.58.

11. Miao EA, Rajan JV. Salmonella and Caspase-1: a complex interplay of detection and evasion. Front Microbiol. 2011;2:85. https://doi.org/10.3389/ fmicb.2011.00085.

12. Jorgensen I, Miao EA. Pyroptotic cell death defends against intracellular pathogens. Immunol Rev. 2015;265(1):130-42. https://doi.org/10.1111/imr. 12287.

13. Martinon F, Burns K, Tschopp J. The inflammasome: a molecular platform triggering activation of inflammatory caspases and processing of proll-beta. Mol Cell. 2002;10(2):417-26. https://doi.org/10.1016/s1097-2765(02)00599-3.

14. Miao EA, Leaf IA, Treuting PM, Mao DP, Dors M, Sarkar A, et al. Caspase-1induced pyroptosis is an innate immune effector mechanism against intracellular bacteria. Nat Immunol. 2010;11(12):1136-42. https://doi.org/10. 1038/ni.1960

15. Raupach B, Peuschel SK, Monack DM, Zychlinsky A. Caspase-1-mediated activation of interleukin-1 beta (IL-1 beta) and IL-18 contributes to innate immune defenses against Salmonella enterica serovar Typhimurium infection. Infect Immun. 2006;74(8):4922-6. https://doi.org/10.1128/IAl. 00417-06.

16. Broz P, Newton K, Lamkanfi M, Mariathasan S, Dixit VM, Monack DM. Redundant roles for inflammasome receptors NLRP3 and NLRC4 in host defense against Salmonella. J Exp Med. 2010;207(8):1745-55. https://doi.org/ 10.1084/jem.20100257.

17. Rosales-Reyes R, Perez-Lopez A, Sanchez-Gomez C, Hernandez-Mote RR, Castro-Eguiluz D, Ortiz-Navarrete V, et al. Salmonella infects B cells by macropinocytosis and formation of spacious phagosomes but does not induce pyroptosis in favor of its survival. Microb Pathog. 2012;52(6):367-74. https://doi.org/10.1016/j.micpath.2012.03.007.

18. Miao EA, Alpuche-Aranda CM, Dors M, Clark AE, Bader MW, Miller SI, et al. Cytoplasmic flagellin activates caspase-1 and secretion of interleukin 1 beta via Ipaf. Nat Immunol. 2006;7(6):569-75. https://doi.org/10.1038/ni1344.

19. Hu GQ, Song PX, Chen W, Qi S, Yu SX, Du CT, et al. Cirtical role for Salmonella effector SopB in regulating inflammasome activation. Mol Immunol. 2017;90:280-6. https://doi.org/10.1016/j.molimm.2017.07.011. 
20. Perez-Lopez A, Rosales-Reyes R, Alpuche-Aranda CM, Ortiz-Navarrete V. Salmonella downregulates nod-like receptor family CARD domain containing protein 4 expression to promote its survival in B cells by preventing inflammasome activation and cell death. J Immunol. 2013;190(3): 1201-9. https://doi.org/10.4049/jimmunol.1200415.

21. Wynosky-Dolfi MA, Snyder AG, Philip NH, Doonan PJ, Poffenberger MC, Avizonis D, et al. Oxidative metabolism enables Salmonella evasion of the NLRP3 inflammasome. J Exp Med. 2014;211(4):653-68. https://doi.org/10. 1084/jem.20130627.

22. Heithoff DM, Sinsheimer RL, Low DA, Mahan MJ. An essential role for DNA adenine methylation in bacterial virulence. Science. 1999;284(5416):967-70. https://doi.org/10.1126/science.284.5416.967.

23. Balbontin R, Rowley G, Pucciarelli MG, Lopez-Garrido J, Wormstone Y, Lucchini $S$, et al. DNA adenine methylation regulates virulence gene expression in Salmonella enterica serovar Typhimurium. J Bacteriol. 2006; 188(23):8160-8. https://doi.org/10.1128/JB.00847-06.

24. Morales VM, Backman A, Bagdasarian M. A series of wide-host-range lowcopy-number vectors that allow direct screening for recombinants. Gene. 1991;97(1):39-47. https://doi.org/10.1016/0378-1119(91)90007-x.

25. Man SM, Kanneganti TD. Converging roles of caspases in inflammasome activation, cell death and innate immunity. Nat Rev Immunol. 2016;16(1):721. https://doi.org/10.1038/nri.2015.7.

26. Keestra-Gounder AM, Tsolis RM, Baumler AJ. Now you see me, now you don't: the interaction of Salmonella with innate immune receptors. Nat Rev Microbiol. 2015;13(4):206-16. https://doi.org/10.1038/nrmicro3428.

27. Mastroeni P, Grant A, Restif O, Maskell D. A dynamic view of the spread and intracellular distribution of Salmonella enterica. Nat Rev Microbiol. 2009;7(1): 73-80. https://doi.org/10.1038/nrmicro2034.

28. Bierschenk D, Monteleone M, Moghaddas F, Baker PJ, Masters SL, Boucher D, et al. The Salmonella pathogenicity island-2 subverts human NLRP3 and NLRC4 inflammasome responses. J Leukoc Biol. 2019;105(2):401-10. https:// doi.org/10.1002/JLB.MA0318-112RR.

29. Boonyom R, Karavolos MH, Bulmer DM, Khan CMA. Salmonella pathogenicity island 1 (SPI-1) type III secretion of SopD involves $\mathrm{N}$ - and Cterminal signals and direct binding to the InvC ATPase. Microbiology. 2010; 156(Pt 6):1805-14. https://doi.org/10.1099/mic.0.038117-0.

30. Eichelberg K, Ginocchio CC, Galan JE. Molecular and functional characterization of the Salmonella typhimurium invasion genes invB and invC: homology of InvC to the FOF1 ATPase family of proteins. J Bacteriol. 1994;176(15):4501-10. https://doi.org/10.1128/jb.176.15.4501-4510.1994

31. Collazo CM, Zierler MK, Galan JE. Functional analysis of the Salmonella typhimurium invasion genes invl and inv and identification of a target of the protein secretion apparatus encoded in the inv locus. Mol Microbiol. 1995;15(1):25-38. https://doi.org/10.1111/j.1365-2958.1995.tb02218.x.

32. Zierler MK, Galan JE. Contact with cultured epithelial cells stimulates secretion of Salmonella typhimurium invasion protein InvJ. Infect Immun. 1995;63(10):4024-8.

33. Stafford GP, Evans LD, Krumscheid R, Dhillon P, Fraser GM, Hughes C. Sorting of early and late flagellar subunits after docking at the membrane ATPase of the type III export pathway. J Mol Biol. 2007;374(4):877-82. https://doi.org/10.1016/j.jmb.2007.09.080.

34. Brumme S, Arnold T, Sigmarsson H, Lehmann J, Scholz HC, Hardt WD, et al. Impact of Salmonella Typhimurium DT104 virulence factors invC and sseD on the onset, clinical course, colonization patterns and immune response of porcine salmonellosis. Vet Microbiol. 2007;124(3-4):274-85. https://doi.org/ 10.1016/j.vetmic.2007.04.032.

35. Hu J, Worrall L, Vuckovic M, Hong C, Deng W, Atkinson CE, et al. T3S injectisome needle complex structures in four distinct states reveal the basis of membrane coupling and assembly. Nat Microbiol. 2019;4(11):2010-9. https://doi.org/10.1038/s41564-019-0545-Z

36. Sukhan A, Kubori T, Wilson J, Galan JE. Genetic analysis of assembly of the Salmonella enterica Serovar Typhimurium type III secretion-associated needle complex. J Bacteriol. 2001;183(4):1159-67. https://doi.org/10.1128/jb. 183.4.1159-1167.2001.

37. Miao EA, Warren SE. Innate immune detection of bacterial virulence factors via the NLRC4 inflammasome. J Clin Immunol. 2010;30(4):502-6. https://doi. org/10.1007/s10875-010-9386-5.

38. Miao EA, Mao DP, Yudkovsky N, Bonneau R, Lorang CG, Warren SE, et al. Innate immune detection of the type III secretion apparatus through the NLRC4 inflammasome. Proc Natl Acad Sci U S A. 2010;107(7):3076-80. https://doi.org/10.1073/pnas.0913087107.
39. Hernday A, Braaten B, Low D. The intricate workings of a bacterial epigenetic switch. Adv Exp Med Biol. 2004;547:83-9. https://doi.org/10.1007/ 978-1-4419-8861-4_7.

40. Pucciarelli MG, Prieto Al, Casadesus J, Garci ADPF. Envelope instability in DNA adenine methylase mutants of Salmonella enterica. Microbiology. 2002;148(Pt 4):1171-82. https://doi.org/10.1099/00221287-148-4-1171.

41. Simon R, Samuel CE. Interleukin-1 beta secretion is activated comparably by FliC and FljB flagellins but differentially by wild-type and DNA adenine methylase-deficient salmonella. J Interf Cytokine Res. 2008;28(11):661-6. https://doi.org/10.1089/jir.2008.0022.

42. Dueger EL, House JK, Heithoff DM, Mahan MJ. Salmonella DNA adenine methylase mutants elicit early and late onset protective immune responses in calves. Vaccine. 2003;21(23):3249-58. https://doi.org/10.1016/s0264410x(03)00252-4.

43. Dueger EL, House JK, Heithoff DM, Mahan MJ. Salmonella DNA adenine methylase mutants elicit protective immune responses to homologous and heterologous serovars in chickens. Infect Immun. 2001;69(12):7950-4. https://doi.org/10.1128/IAl.69.12.7950-7954.2001.

44. Mohler VL, Heithoff DM, Mahan MJ, Hornitzky MA, Thomson PC, House JK Development of a novel in-water vaccination protocol for DNA adenine methylase deficient Salmonella enterica serovar Typhimurium vaccine in adult sheep. Vaccine. 2012;30(8):1481-91. https://doi.org/10.1016/j.vaccine. 2011.12.079.

45. Mohler VL, Heithoff DM, Mahan MJ, Walker KH, Hornitzky MA, McConnell CS, et al. Cross-protective immunity in calves conferred by a DNA adenine methylase deficient Salmonellaenterica serovar Typhimurium vaccine. Vaccine. 2006;24(9):1339-45. https://doi.org/10.1016/j.vaccine.2005.09.022.

46. Mohler VL, Heithoff DM, Mahan MJ, Walker KH, Hornitzky MA, Shum LW, et al. Cross-protective immunity conferred by a DNA adenine methylase deficient Salmonella enterica serovar Typhimurium vaccine in calves challenged with Salmonella serovar Newport. Vaccine. 2008;26(14):1751-8. https://doi.org/10.1016/j.vaccine.2008.01.018.

47. Giacomodonato MN, Sarnacki SH, Llana MN, Cerquetti MC. Dam and its role in pathogenicity of Salmonella enterica. J Infect Dev Ctries. 2009;3(7):484-90. https://doi.org/10.3855/jidc.465.

48. Huang Y, Peng Y, Sun J, Li S, Hong J, Zhou J, et al. Nicotinamide Phosphoribosyl Transferase controls NLRP3 Inflammasome activity through MAPK and NF-kappaB signaling in nucleus Pulposus cells, as suppressed by melatonin. Inflammation. 2020. https://doi.org/10.1007/s10753-019-01166-z.

49. Watanabe A, Sohail MA, Gomes DA, Hashmi A, Nagata J, Sutterwala FS, et al. Inflammasome-mediated regulation of hepatic stellate cells. Am J Physiol Gastrointest Liver Physiol. 2009;296(6):G1248-57. https://doi.org/10.1152/ ajpgi.90223.2008.

50. Yabal M, Muller N, Adler H, Knies N, Gross CJ, Damgaard RB, et al. XIAP restricts TNF- and RIP3-dependent cell death and inflammasome activation. Cell Rep. 2014;7(6):1796-808. https://doi.org/10.1016/j.celrep.2014.05.008.

51. Alvarez S, Munoz-Fernandez MA. TNF-alpha may mediate inflammasome activation in the absence of bacterial infection in more than one way. PLoS One. 2013;8(8):e71477. https://doi.org/10.1371/journal.pone.0071477.

52. Liu Y, Zhang W, Wu X, Gong J. Foxo3a-dependent Bim transcription protects mice from a high fat diet via inhibition of activation of the NLRP3 inflammasome by facilitating autophagy flux in Kupffer cells. Oncotarget. 2017:8(21):34258-67. https://doi.org/10.18632/oncotarget.15946.

53. He W, Long T, Pan Q, Zhang S, Zhang Y, Zhang D, et al. Microglial NLRP3 inflammasome activation mediates IL-1beta release and contributes to central sensitization in a recurrent nitroglycerin-induced migraine model. J Neuroinflammation. 2019;16(1):78. https://doi.org/10. 1186/s12974-019-1459-7.

54. Li H, Zhang X, Chen M, Chen J, Gao T, Yao S. Dexmedetomidine inhibits inflammation in microglia cells under stimulation of LPS and ATP by c-Fos/ NLRP3/caspase-1 cascades. EXCLI J. 2018;17:302-11. https://doi.org/10. 17179/excli2017-1018.

55. Campbell PM. Oncogenic Ras pushes (and pulls) cell cycle progression through ERK activation. Methods Mol Biol. 2014;1170:155-63. https://doi. org/10.1007/978-1-4939-0888-2_9.

56. Hajek E, Krebs F, Bent R, Haas K, Bast A, Steinmetz I, et al. BRAF inhibitors stimulate inflammasome activation and interleukin 1 beta production in dendritic cells. Oncotarget. 2018;9(47):28294-308. https://doi.org/10.18632/ oncotarget.25511.

57. Wan P, Zhang Q, Liu W, Jia Y, Ai S, Wang T, et al. Cullin1 binds and promotes NLRP3 ubiquitination to repress systematic inflammasome 
activation. FASEB J. 2019;33(4):5793-807. https://doi.org/10.1096/fj. 201801681R.

58. Huang CF, Chen L, Li YC, Wu L, Yu GT, Zhang WF, et al. NLRP3 inflammasome activation promotes inflammation-induced carcinogenesis in head and neck squamous cell carcinoma. J Exp Clin Cancer Res. 2017;36(1): 116. https://doi.org/10.1186/s13046-017-0589-y.

59. Martin BN, Wang C, Willette-Brown J, Herjan T, Gulen MF, Zhou H, et al. IKKalpha negatively regulates ASC-dependent inflammasome activation. Nat Commun. 2014;5:4977. https://doi.org/10.1038/ncomms5977.

60. Miao H, Ou J, Zhang X, Chen Y, Xue B, Shi H, et al. Macrophage CGI-58 deficiency promotes IL-1 beta transcription by activating the SOCS3-FOXO1 pathway. Clin Sci (Lond). 2015;128(8):493-506. https://doi.org/10.1042/ CS20140414.

61. Zou P, Liu X, Li G, Wang Y. Resveratrol pretreatment attenuates traumatic brain injury in rats by suppressing NLRP3 inflammasome activation via SIRT1. Mol Med Rep. 2018;17(2):3212-7. https://doi.org/10. 3892/mmr.2017.8241.

62. Cristina Cerquetti M, Hovsepian E, Sarnacki SH, Goren NB. Salmonella enterica serovar Enteritidis dam mutant induces low NOS-2 and COX-2 expression in macrophages via attenuation of MAPK and NF-kappaB pathways. Microbes Infect. 2008;10(14-15):1431-9. https://doi.org/10.1016/j. micinf.2008.08.008

63. Okada M, Matsuzawa A, Yoshimura A, Ichijo H. The lysosome ruptureactivated TAK1-JNK pathway regulates NLRP3 inflammasome activation. J Biol Chem. 2014;289(47):32926-36. https://doi.org/10.1074/jbc.M1 14.579961.

64. Hara H, Tsuchiya K, Kawamura I, Fang R, Hernandez-Cuellar E, Shen Y, et al. Phosphorylation of the adaptor ASC acts as a molecular switch that controls the formation of speck-like aggregates and inflammasome activity. Nat Immunol. 2013;14(12):1247-55. https://doi.org/10.1038/ni.2749.

65. Dumont A, de Rosny C, Kieu TL, Perrey S, Berger H, Fluckiger A, et al. Docosahexaenoic acid inhibits both NLRP3 inflammasome assembly and JNK-mediated mature IL-1beta secretion in 5-fluorouracil-treated MDSC: implication in cancer treatment. Cell Death Dis. 2019;10(7):485. https://doi. org/10.1038/s41419-019-1723-x.

66. Chen H, Yang D, Han F, Tan J, Zhang L, Xiao J, et al. The bacterial T6SS effector EvpP prevents NLRP3 Inflammasome activation by inhibiting the $\mathrm{Ca}(2+)$-dependent MAPK-Jnk pathway. Cell Host Microbe. 2017;21(1):47-58. https://doi.org/10.1016/j.chom.2016.12.004.

67. Munoz-Planillo R, Kuffa P, Martinez-Colon G, Smith BL, Rajendiran TM, Nunez G. K(+) efflux is the common trigger of NLRP3 inflammasome activation by bacterial toxins and particulate matter. Immunity. 2013;38(6):1142-53. https://doi.org/10.1016/.immuni.2013.05.016.

68. Tschopp J, Schroder K. NLRP3 inflammasome activation: the convergence of multiple signalling pathways on ROS production? Nat Rev Immunol. 2010; 10(3):210-5. https://doi.org/10.1038/nri2725.

69. Shi X, Ye H, Yao X, Gao Y. The involvement and possible mechanism of NR4A1 in chondrocyte apoptosis during osteoarthritis. Am J Transl Res. 2017:9(2):746-54.

70. Mahalingam D, Carew JS, Espitia CM, Cool RH, Giles FJ, de Jong S, et al, Heightened JNK Activation and Reduced XIAP Levels Promote TRAIL and Sunitinib-Mediated Apoptosis in Colon Cancer Models. Cancers (Basel). 2019;11(7). https://doi.org/10.3390/cancers11070895.

71. Vivanco I, Palaskas N, Tran C, Finn SP, Getz G, Kennedy NJ, et al. Identification of the JNK signaling pathway as a functional target of the tumor suppressor PTEN. Cancer Cell. 2007;11(6):555-69. https://doi.org/10. 1016/j.ccr.2007.04.021.

72. Zhao X, Wu Y, Li J, Li D, Jin Y, Zhu P, et al. JNK activation-mediated nuclear SIRT1 protein suppression contributes to silica nanoparticle-induced pulmonary damage via p53 acetylation and cytoplasmic localisation Toxicology. 2019;423:42-53. https://doi.org/10.1016/j.tox.2019.05.003.

73. Lee GS, Subramanian N, Kim Al, Aksentijevich I, Goldbach-Mansky R, Sacks $\mathrm{DB}$, et al. The calcium-sensing receptor regulates the NLRP3 inflammasome through Ca2+ and cAMP. Nature. 2012;492(7427):123-7. https://doi.org/10. 1038/nature11588

74. Chiang SL, Rubin EJ. Construction of a mariner-based transposon for epitope-tagging and genomic targeting. Gene. 2002;296(1-2):179-85. https://doi.org/10.1016/s0378-1119(02)00856-9.

75. Wang SY, Lauritz J, Jass J, Milton DL. A ToxR homolog from Vibrio anguillarum serotype $\mathrm{O} 1$ regulates its own production, bile resistance, and biofilm formation. J Bacteriol. 2002;184(6):1630-9. https://doi.org/10.1128/jb. 184.6.1630-1639.2002.
76. Charpentier $X$, Oswald E. Identification of the secretion and translocation domain of the enteropathogenic and enterohemorrhagic Escherichia coli effector Cif, using TEM-1 beta-lactamase as a new fluorescence-based reporter. J Bacteriol. 2004;186(16):5486-95. https://doi.org/10.1128/JB.186.16. 5486-5495.2004

77. Francis MS, Amer AA, Milton DL, Costa TR. Site-directed mutagenesis and its application in studying the interactions of T3S components. Methods Mol Biol. 2017;1531:11-31. https://doi.org/10.1007/978-1-4939-6649-3_2.

78. OToole GA, Kolter R. Initiation of biofilm formation in Pseudomonas fluorescens WCS365 proceeds via multiple, convergent signalling pathways: a genetic analysis. Mol Microbiol. 1998;28(3):449-61. https://doi.org/10.1046/ j.1365-2958.1998.00797.x.

79. Assouvie A, Daley-Bauer LP, Rousselet G. Growing murine bone marrowderived macrophages. Methods Mol Biol 2018;1784:29-33; doi: https://doi. org/10.1007/978-1-4939-7837-3_3.

80. Lee CA, Falkow S. The ability of Salmonella to enter mammalian cells is affected by bacterial growth state. Proc Natl Acad Sci U S A. 1990;87(11): 4304-8. https://doi.org/10.1073/pnas.87.11.4304.

81. Liu Y, Zhao L, Yang M, Yin K, Zhou X, Leung KY, et al. Transcriptomic dissection of the horizontally acquired response regulator EsrB reveals its global regulatory roles in the physiological adaptation and activation of T3SS and the cognate effector repertoire in Edwardsiella piscicida during infection toward turbot. Virulence. 2017;8(7):1355-77. https://doi.org/10. 1080/21505594.2017.1323157.

82. Malo N, Hanley JA, Cerquozzi S, Pelletier J, Nadon R. Statistical practice in high-throughput screening data analysis. Nat Biotechnol. 2006;24(2):167-75. https://doi.org/10.1038/nbt1186.

\section{Publisher's Note}

Springer Nature remains neutral with regard to jurisdictional claims in published maps and institutional affiliations.
Ready to submit your research? Choose BMC and benefit from:

- fast, convenient online submission

- thorough peer review by experienced researchers in your field

- rapid publication on acceptance

- support for research data, including large and complex data types

- gold Open Access which fosters wider collaboration and increased citations

- maximum visibility for your research: over $100 \mathrm{M}$ website views per year

At $\mathrm{BMC}$, research is always in progress.

Learn more biomedcentral.com/submissions 